\title{
N. F. S. Grundtvigs syn på forholdet mellem Skabelse, Åbenbaring og Nærværelse belyst ved en sammenligning med Jürgen Moltmann
}

\section{Af Betina Hjorth Proestegaard}

Der er brug for teologer som N. F. S. Grundtvig og Jürgen Moltmann, hvis teologien ikke kun skal være for skolen og intellektet, men også skal have en plads i kirkens og livets rum. For dem er dogmatik mere end en privat reflekteret viden om Guds væsen og en akademisk resignation over for en erfaringsmæssig erkendelse af Gudsnærværet. Både Grundtvig og Moltmann tolker det kristne budskab som en aktuel og vedkommende livssandhed.

Når dogmatikken derfor bliver en troslære formuleret i respekt for sit emnes universelle og ontologiske karakter, betyder det, at sondringen mellem teologien som en teoretisk og praktisk disciplin må nedtones. Denne erkendelse ligger til grund for såvel Grundtvigs som Moltmanns bestræbelser på at lade teologien afspejle et levende og nærværende gudsbillede. Dermed leverer begge teologer et prisværdigt forsøg på at overvinde den sondring mellem Guds Åbenbaring og menneskets historie, som især i Vestkirken er blevet den teologiske konsekvens af bl.a. Kants kritik af metafysikken.

Det er tankevækkende, at Grundtvig og Moltmann på trods af de 150 år, der skiller dem, synes at stå i et lignende opgør med hovedstrømninger i vores vestkirkelige tradition, der fortsat kan klandres for at holde teologien fanget $i$ et postkantiansk, epistemologisk, etisk, psykologisk og individcentreret jerngreb. Når to ellers så forskellige teologer kan mødes i en fælles kritik af Vestkirken, bekræfter det en mistanke om, at hovedparten af de vestkirkelige teologer har lukket øjnene for vigtige tankemønstre i den østkirkelige tradition. Østkirkens teologi-såvel som anglikansk teologi, der i større grad driver på østkirkeligt gods - repræsenterer nemlig en helt anderledes liturgisk, praktisk, social og ontologisk indfaldsvinkel til kristendommen, som Grundtvig og Moltmann altså udmærker sig ved at tage alvorligt.

I den nærværende artikel vil det især dreje sig om Grundtvigs og Moltmanns kritik af den vestkirkelige teologis gudsbillede. Inspireret af et østkirkeligt trinitarisk gudsbillede forsøger de begge at opstille et alternativ til den vestkirkelige traditions gængse inddeling af trinitetslæ- 
ren i henholdsvis en immanent og økonomisk trinitetslære ${ }^{1}$. Denne sondring mellem en immanent og økonomisk trinitetslære, som både Grundtvig og Moltmann opponerer mod, bør ses som en variant af deres intention om at mægle mellem teologien som en teoretisk og praktisk disciplin. Igen gælder det, at kun hvis spaltningen mellem den immanente og økonomiske trinitet nedtones, således at evangeliet fortsat repræsenterer en vedkommende og ontologisk livssandhed, har kristendommen ifølge Grundtvig og Moltmann en fremtid.

Der hersker i forbindelse med trinitetslæren en tendens til, at vestkirkelige teologer udelukkende fokuserer på de to første trosartikler i Trosbekendelsen. Dette sker foranlediget af en altdominerende interesse for Inkarnationens primært soteriologiske og etiske betydning som en retfærdiggørende nådes-handling. Hos både Grundtvig og Moltmann rettes blikket derimod, som det vil fremgå, mod såvel Faderen og Sønnen som Helligånden. De to teologers fokus på det trinitariske fællesskab og Helligåndens Nærværelse vil i denne artikel blive fremhævet som en slags fikspunkt for deres fælles kritik af de vestkirkelige kollegers kristomonistiske teologi ${ }^{2}$. Inspireret af den østkirkelige trinitariske bevidsthed fremhæver både Grundtvig og Moltmann i deres apologi for kristendommens ontologiske og nutidige relevans med andre ord spørgsmålet om forholdet mellem Skabelse, Åbenbaring og Nærværelse (dvs. forholdet mellem de tre trosartikler) som teologiens fornemste opgave.

Spørgsmålet om forholdet mellem Skabelse, Åbenbaring og Nærværelse vil ikke overraskende komme til at dvæle ved forholdet mellem den anden og tredje trosartikel. Som antydet er det især i relationen mellem kristologi og pneumatologi, at Grundtvigs og Moltmanns skæringspunkt skal findes i deres fælles trinitariske alternativ til den vestkirkelige teologi. I artiklens første del præciseres de allerede her antydede fællestræk mellem de to forfatterskaber, idet der stilles skarpt på deres fælles udgangspunkt i tanken om et trinitarisk Nærvær.

Det er imidlertid bemærkelsesværdigt, at de to teologers trinitariske skæringspunkt og ikke mindst deres pneumatologiske interesse ved nærmere eftersyn ligeledes skal vise sig at være det punkt, der bedst afslører deres forskellighed. I artiklens anden del stilles der skarpt på Grundtvigs og Moltmanns nadversyn som en kilde til forståelsen af deres divergerende tanker om det trinitariske Nærvær. Nadveren bliver med andre ord en slags vindue, hvorigennem den trinitariske teologi betragtes i aktion på nært hold. Mens nadveren hos Moltmann får begrænset omtale, findes der talrige nadvertekster fra Grundtvigs hånd. I nærværende 
analyse fremhæves især salmerne fra første bind af Grundtvigs SangVoerk (GSV) udgivet i $1837^{3} \mathrm{og}$ prædikenerne fra samme år ${ }^{4}$. Som Chr. Thodberg har gjort opmærksom på, markerer teksterne fra 1837 nemlig måske et klimaks for Grundtvigs fascination af spørgsmålet om Guds Nærvær. Dette skyldes ikke mindst, at Grundtvig ved påsketid dette år gennem en græsk liturgibog for alvor stifter bekendtskab med den græsk-ortodokse teologi $i^{5}$ Med hensyn til Moltmann koncentrerer analysen sig især om hans nadverreferencer i bogen Kirche in der Kraft des Geistes $(K K G)^{6}$ og i hans nyeste værk, Erfahrungen Theologischen Denkens $(E T D)^{7}$.

Fordi Grundtvig og Moltmann står med benene dybt forankret i hver deres gren af den vestkirkelige postreformatoriske tradition, vil der i nadveranalysen ske en form for indsnævring af den økumeniske debat. Her drejer det sig som i artiklens første del ikke længere kun om forskelle mellem Øst- og Vestkirken men i lige så høj grad om forskelle og spændinger inden for rammerne af den vestkirkelige teologihistorie. Med valget af Moltmann som Grundtvigs samtalepartner følger nemlig foruden en chance for at fokusere på forholdet mellem den østkirkelige og vestkirkelige teologi ligeledes en god mulighed for at betragte og analysere forskellige vestkirkelige tankemønstre.

Artiklens tredje del præciserer de forskelle mellem Grundtvig og Moltmann, som allerede blev antydet gennem arbejdet med de to teologers meget forskellige nadvertekster. Endvidere bliver det især i denne tredje del tydeligt, hvordan analyser som denne, hvor Grundtvig sammenlignes med en nulevende teolog, kan tilføre ny energi til den i mange år lidt fastlåste hjemlige Grundtvig-debat. Dermed sympatiserer artiklen med de senere års ønske om at påpege Grundtvig-litteraturens fortsatte potentiale ikke mindst i en international og økumenisk kontekst ${ }^{8}$.

\section{I: Ligheder mellem Grundtvig og Moltmann}

Grundtvigs og Moltmanns opgør med Vestkirkens monarkiske trinitetsloere og et autonomt personbegreb

Både Grundtvigs og Moltmanns teologi kan læses som et opgør med den gren af den vestkirkelige teologihistorie, som Moltmann refererer til som »den monarkiske trinitetslære«. Moltmann inddeler trinitetslæren i en monarkisk, en eukaristisk og en doksologisk trinitetslære (»das monarchische, eucharistische und doxologische Konzept der Trinität «) ${ }^{9}$. 
Denne treleddede inddeling er meget klargørende for en dybere forståelse af de forskellige fronter i den økumeniske dialog og understreger meget godt den fortsatte aktualitet i Grundtvigs teologi.

Mens den monarkiske trinitetslære er den mest gængse form for trinitetslære i Vestkirken, møder man i Østkirken (såvel som i Grundtvigs teologi) især den eukaristiske udformning af trinitetslæren ${ }^{10}$. Den doksologiske trinitetslære er Moltmanns eget alternativ til de to traditioner.

Hverken Grundtvig eller Moltmann kan tilslutte sig den monarkiske trinitetslæres autoritative Gudsbillede, som bl.a. kendes fra termen Gott an sich (Kant) og fra talen om Gud som en uforanderlig substans (Aristoteles, Augustin) og et isoleret subjekt (den tidlige Barth, Kierkegaard). Denne trinitetslære, som Moltmann et andet sted kalder »den spekulative eller filosofiske trinitetslære ${ }^{11}$ opererer i sit fokus på det guddommelige fraver med et abstrakt begreb om Guds transcendente enhed.

Moltmann kalder ikke overraskende den monarkiske trinitetslære for den monarkiske monoteisme. Guds enhed betones i denne trinitetsmodel nemlig på bekostning af talen om de tre personer ${ }^{12}$. At denne model dermed ifølge Moltmann let tenderer til modalisme ${ }^{13}$ ses måske mest markant i relation til pneumatologien, idet Helligånden til tider i den vestkirkelige tradition helt og holdent er blevet identificeret med en slags relationel kraft til forskel fra en med Faderen og Sønnen ligeværdig person ${ }^{14}$. Faktisk relaterer gudsforholdet i denne kristomonistiske model sig i altoverskyggende grad til forholdet mellem Faderen og Sønnen - dvs. til Åbenbaringen udlagt som en éngangsbegivenhed i fortiden.

Når Gud, som i den monarkiske trinitetslære, »reduceres« til en vertikal brydning af historien sker der, som også $\mathrm{H}$. Thomsen gør opmærksom $\mathrm{pa}^{15}$, en spatiering af den immanente og økonomiske trinitetslære, som hverken Moltmann eller Grundtvig kan acceptere i deres ønske om en ontologisk og frelseshistorisk indfaldsvinkel til teologien. Ikke desto mindre har denne spatiering præget megen vestkirkelig teologi, siden Kant definitivt separerede Gott an sich fra Gott für mich. Da spatieringen i virkeligheden dækker over en frygt for at indfange Gud i menneskelige kategorier, er det tankevækkende, når Moltmann flere steder skriver, at f.eks. Barths monarkiske Gudsbillede er en transcendering af subjektsfilosofiens menneskesyn, således at det transcendente i virkeligheden, som også Feuerbach hævdede, i den monarkiske trinitetslære er identisk med det selvtranscendente ${ }^{16}$. Verdslige 
magts- og subjekts-prædikater overføres på Gudsbilledet, og det monarkiske personbegreb får i sit forsvar for Guds almagt og frihed et indhold, der afspejler det sekulariserede samfunds individcentrering. Hvis Moltmann har ret, ender Guds frihed paradoksalt nok i ufrihed, for da er Gud alene produktet af en spekulativ immanent trinitetslære. Dette er selvfølgelig helt imod hensigten, idet især den monarkiske trinitetslære ønsker at tage Kants tale om, at mennesket ikke kan nå til teoretisk viden om Gud, alvorlig.

Mens Moltmann åbenlyst gør op med den monarkiske trinitetslære, er opgøret hos Grundtvig mere implicit, men ikke desto mindre væsentligt. Moltmanns forfatterskab er især præget af opgøret med Bultmanns og Barths udgave af den monarkiske trinitetslære. Han kritiserer i særdeleshed den yngre Barths transcendente Gudsbillede og hans kristomonistiske fokus på Åbenbaringen »senkrecht von oben « ${ }^{17}$. Grundtvigs teologi kan siges at afspejle et lignende opgør med en anden udgave af den monarkiske trinitetslære. Det gælder hans kritik af Kierkegaard, der taler om Gudsforholdet som et "paradoks«.

Grundtvigs og Moltmanns trinitariske Gudsbillede og den eukaristiske trinitetsloere

I modsætning til det vestkirkelige fokus på inkarnationen og tonaturlæren udmærker Grundtvig og Moltmann sig ved i deres livslange kamp mod den monarkiske trinitetslære at fokusere på et trinitarisk Gudsbillede. Grundtvigs og Moltmanns teologi kan med andre ord læses som en slags meditation over Den Apostolske Trosbekendelse.

Ved hjælp af treenighedslæren og ikke mindst ved hjælp af en fornyet pneumatologisk bevidsthed mener Grundtvig og Moltmann at kunne forsvare kristendommens aktualitet som en vedkommende livssandhed. De kredser omkring tanken om et trinitarisk Nærvær ${ }^{18}$ og lægger sig begge i forlængelse af østkirkens eukaristiske trinitetslære.

Den eukaristiske trinitetslæres rødder forgrener sig langt ind i den græsk-ortodokse teologihistorie og bærer tydeligt præg af denne traditions helt anderledes liturgiske og praktiske indfaldsvinkel til de dogmatiske spørgsmål. Den eukaristiske trinitetslæres Sitz im Leben er gudstjenesten og ikke mindst nadverfejringen ${ }^{19}$, der fremhæves som et slags billede på menneskets indlemmelse i det guddommelige trinitariske liv. I det hele taget spiller menneskets deltagelse i det guddommelige liv en vigtig rolle i denne trinitetsmodel, hvis fokus i høj grad er 
Helligåndens inhabitation og integrerende virke i menighedens lovsang og tro.

På vore breddegrader kendes fokuset på det trinitariske Nærvær bl.a. fra den engelske kirkehistorie, hvor tankemønstre fra den græsk-ortodokse kirke især genfindes hos metodisterne. Af den grund burde danske Grundtvig-forskere måske i endnu højere grad rette blikket mod vest frem for mod syd, som vi ellers har for vane i vores udprægede lutherske og tysksindede teologiske bevidsthed ${ }^{20}$.

\section{Grundtvigs og Moltmanns brug af den anden åndstradition}

I umiddelbar forlængelse af talen om den monarkiske trinitetslære over for den eukaristiske trinitetslære følger ikke overraskende talen om den tredje trosartikels betydning. Mens den vestkirkelige teologihistorie er et meget godt eksempel på, at første og anden trosartikel udmærket kan klare sig uden tredje trosartikel, er det kendetegnende for Grundtvig og Moltmann, at deres teologi ikke kan klare sig uden tredje trosartikel. Metodisten L. W. Wood har meget sigende kaldt Moltmanns trinitetslære for »en pneumatologisk trinitetslære» (»a trinitarian pneumato$\log ($ «), fordi hans indfaldsvinkel til trinitetslæren er Kristus-begivenheden læst som Helligåndshistorie ${ }^{21}$. Hos Grundtvig er det måske endnu klarere, at mennesket kommer baglæns ind i triniteten, nemlig via Helligåndens gave knyttet til dåben. Begge teologer præsterer med andre ord en slags trinitarisk eksegese, der viser en for deres tradition ellers sjælden interesse for den tredje trosartikel. Dermed kan de siges at repræsentere den åndstradition, som sigende har fået betegnelsen »GeistChristologie $\ll^{22}$.

Traditionelt taler man om to forskellige åndstraditioner, dvs. to forskellige syn på forholdet mellem kristologi og pneumatologi ${ }^{23}$. De to åndstraditioner bygger på hver sit nytestamentlige forlæg. Den første åndstradition, der har en tendens til at sætte tredje trosartikel i skyggen af anden trosartikel, møder vi primært i Johannes-evangeliet og i Pauluslitteraturen. Det kristomonistiske aspekt i denne åndstradition, der fokuserer på Logos' inkarnation, kommer bl.a. til udtryk i Johannes-evangeliets sidste kapitler i talen om Parakleten. Kendetegnende er det, at Parakleten i Johannes-evangeliet følger efter Kristus i tid såvel som i rang. Parakleten eller Helligånden indsættes til sin gerning af Sønnen, akkurat som Faderen indsatte Sønnen. Dermed subordineres Helligånden i forhold til Faderen og Sønnen. Den første åndstradition kan derfor til 
dels siges at forberede tilføjelsen af ordet filioque til Den nicænoconstantinopolitanske Trosbekendelses tredje trosartikel. Tilføjelsen af ordet filioque til den vestkirkelige variant af Nicæno Constantinopolitanum har siden Oldkirken været et slags symbol på forskellen mellem den vestkirkelige, kristomonistiske og monarkiske teologi på den ene side og den østkirkelige og trinitariske teologi på den anden side ${ }^{24}$.

Den anden åndstradition derimod bevarer en anderledes trinitarisk tilgang til gudsbilledet gennem tanken om Åndens tilstedeværelse i såvel Skabelsen som i Kristus-begivenheden og i historien i det hele taget. Denne ånds-kristologiske åndstradition findes primært i de synoptiske evangelier og foregribes i Det Gamle Testamentes pneumatologi. Det er altså denne anden åndstradition såvel Grundtvig som Moltmann bygger videre på i deres trinitariske og pneumatologiske bevidsthed.

Den vestkirkelige traditions favorisering af de to første trosartikler og den første åndstradition må på foruroligende vis siges at gøre teologien fremmed for den tradition, der kendetegner den kirkelige praksis, hvor bekendelsen fortsat gælder den treenige Gud. Kirkeårets pejlemærker er foruden julen og påsken fortsat pinsen, med fejringen af Helligåndens Nærvær. Både Grundtvig og Moltmann virkede og virker som præster. Måske derfor har de begge en prisværdig intention om at forene verden inden for kirken med verden uden for kirken.

Grundtvig og Moltmann og den oldgrceske tanke om Perichoresis: Et inter-subjektivt personbegreb

Når det gælder trinitetslærens klassiske spørgsmål om forholdet mellem de tre trosartikler, griber Grundtvig og Moltmann begge fat i tanker, der minder om den oldgræske tale om Perichoresis ${ }^{25}$. Ved hjælp af Perichoresis-begrebet er det muligt at fremmane et intersubjektivt personbegreb, der snarere end at fokusere på Guds frihed og Gud som den uforanderlige substans fokuserer på Guds kærlighed og Gud som det trinitariske foellesskab mellem Faderen, Sønnen og Helligånden. Den østkirkelige coinonia- og communio-bevidsthed spiller dermed en vigtig rolle i begge forfatterskaber.

Med brugen af ordet Perichoresis i forbindelse med indkredsningen af et alternativt personbegreb understreges den tætte relation mellem person og fællesskab, samtidig med at der intenderes et billede af et levende og ikke statisk guddommeligt Nærvær. Moltmann sætter i ETD Perichoresis-tanken i umiddelbar forbindelse med den jødiske tale om 
Schechina (Guds Nærvær oprindeligt knyttet til pagtens ark, siden til templet og under eksilet til folket) og den latinske tale om Circumincessio. Moltmann mener, at den gammeltestamentlige Schechinateologi i Det Nye Testamente ses overført på Kristus-begivenheden. I Det Nye Testamente virker Kristus med andre ord som stedet for den trinitariske Guds Nærvær ${ }^{26}$.

Moltmann oversætter meget sigende Perichoresis til det tyske »die wechselseitige Einwohnung «. Han skriver, at ordet Perichoresis betyder "Wirbel oder Rotation «, og at det i verbalform dækker over en kredsende vekselvirkende bevægelse mellem to eller flere personer ${ }^{27}$. Tanken ledes hen på en slags kædedans ${ }^{28}$.

Grundtvig selv nævner aldrig begrebet direkte, men spørgsmålet er, om ikke Perichoresis-begrebet er i tæt familie med den gængse tale om en grundtvigsk vekselvirkningstanke? Begge begreber giver associationer til et levende, vedvarende og åbent fællesskab. A. M. Allchin introducerer talen om Perichoresis i sin beskrivelse af Grundtvigs trinitetslære $^{29}$. Dette synes meget naturligt og virker som en frugtbar perspektivering.

Perichoresis, der i forbindelse med kristologien betegner de to naturers indbyrdes forhold »uden adskillelse og uden sammenblanding $\aleph^{30}$, overføres altså her på trinitetslæren og bliver hos både Grundtvig og Moltmann kernen i det nye personbegreb. Det nye perichoresiske personbegreb erstatter med andre ord talen om una substantia - tres personae.

Gud er korlighed: Perichoresis-begrebet og den kristne koerlighedstanke

Kærlighed bliver det ord, der bedst forklarer det perichoresiske aspekt ${ }^{31}$. Dermed tænkes den græske Perichoresis-tanke sammen med den kristne kærlighedstanke. Et centralt bibelsted for begge teologer er derfor ikke overraskende Joh. 3.16. Både Grundtvig og Moltmann bruger ordet kærlighed som det vigtigste gudsprædikat ${ }^{32}$. Af Moltmanns bog Der gekreuzigte Gott fremgår det helt eksplicit, at kærlighedstanken i højere grad knytter prædikater som solidaritet og sympatia til Guds væsen frem for prædikatet apatia, der ellers i teologihistorien ofte er blevet brugt som gudsprædikat ${ }^{33}$. Som i feministteologiens gudsbillede understreger kærlighedstanken Guds moderlige, følsomme og feminine sider på bekostning af de maskuline og rationelle træk. 
Kærlighedstanken indeholder et dynamisk aspekt, fordi der i kærlighed er tale om et særligt intersubjektivt personbegreb, som svarer til Perichoresis-begrebet. I kærligheden forenes den elskende og det elskede, Gud og mennesket, samtidig med at den elskende og ikke den elskede ses som den aktive part og forholdets initiativtager. Med andre ord er den trinitariske Gud på én gang kærlighedens subjekt samtidig med, at den trinitariske kærlighed på grund af kærlighedens intersubjektive natur er rettet mod et objekt, som indsluses i det trinitariske kærlighedsfællesskab. Det indbyrdes kærlighedsfællesskab mellem de tre personer i triniteten åbner sig altså naturligt for en indlemmelse af mennesket. Dette kommer fint til udtryk i Moltmanns tale om triniteten som »die offene Trinität $~^{34}{ }^{4}$. En trinitetsteologi med kærligheden som fortegn har med andre ord en integrerende og verdensåben karakter ${ }^{35}$. Ikke overraskende fokuserer Grundtvig og Moltmann derfor gang på gang på de tre guddommelige personers forskellige historiske virke. Personerne omtales ofte i handlingskategorier, idet både Grundtvig og Moltmann repræsenterer en frelseshistorisk indfaldsvinkel til trinitetslæren.

Med andre ord underbygger den perichoresiske kærlighedstanke det fokus på det kristne budskabs kosmiske og ontologiske relevans, som såvel Grundtvig som Moltmann ønsker at forsvare. Dermed sker der i talen om den perichoresiske kærlighedstanke en præcisering af talen om det trinitariske Nærvær. Den perichoresiske kærlighedstanke er på mange måder brændpunktet for sammenligningen af Grundtvigs og Moltmanns syn på forholdet mellem Skabelse, Åbenbaring og Nærværelse.

Grundtvigs og Moltmanns ønske om at overvinde en rigid sondring mellem en immanent og økonomisk trinitetslore og deres forsvar for teologien som såvel en teoretisk som praktisk disciplin

Når Guds person kvalificeres af Faderens, Sønnens og Helligåndens perichoresiske og integrerende kærligheds-fællesskab nedbrydes naturligt den mur mellem en immanent og økonomisk trinitetslære, som ellers ofte opretholdes i vestkirkelige teologers bevidsthed.

Tolkningen af forholdet mellem den immanente og økonomiske trinitetslære, der må siges at være dogmatikhistoriens kerneproblem, hænger tæt sammen med talen om en teoretisk og praktisk fornuft ${ }^{36}$. Denne epistemologiske variant af problemstillingen er især blusset op i kølvandet på Kants erkendelsesteorier. I Østkirken er sondringen mel- 
lem skole og kirke eller samfund aldrig fuldbyrdet, hvilket afspejler sig $i$ en helt anderledes ontologisk indfaldsvinkel til det kristne budskab.

Allerede i Oldkirken kom en variant af problemstillingen imidlertid til udtryk under navn af forholdet mellem theologia prima og theologia secunda. Dengang var der i modsætning til nu ingen tvivl om, at den kritiske teologiske refleksion skulle ske i relation til den kirkelige praksis og den fælles-menneskelige erfaring af Gudsnærværet.

Ved hjælp af inspirationen fra den eukaristiske trinitetslære og det perichoresiske virkelighedssyn lykkes det Grundtvig og Moltmann at forsvare kristendommens ontologiske relevans uden at ende i den anden grøft, hvor teologien bliver til autoritær og fundamentalistisk ortodoksi. De lader ikke hånt om den kritiske eftertanke, men er begge dogmatisk reflekterende på den erfaring af den trinitariske Guds Nærvær, som de mener at opleve i henholdsvis kirkerummet (Grundtvig) og verdenshistorien (Moltmann). Sondringen mellem theologia prima og theologia secunda underkendes med andre ord ikke af nogen af dem. Blot under-

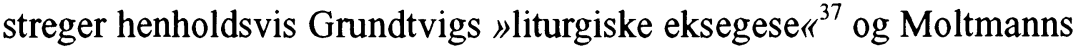
»historieteologiske metode $\ll^{38}$, at teologien ikke bør blive stående i denne sondring.

Grundtvigs og Moltmanns ontologiske fokus: Et opgør med det sekulariserede virkelighedssyn

En for skarp sondring mellem teologien behandlet som en teoretisk akademisk videnskab på den ene side og en praktisk tros-bekendelse på den anden side kan fremhæves som en af de væsentligste årsager til sekulariseringen af det moderne samfund. Kristendommen er på vore breddegrader som et naturligt resultat af det ovenfor skitserede individcentrerede og monarkiske personbegreb især blevet relateret til den private sfære i en interesse for det enkelte menneskes religiøse selv-erkendelse. På grund af den monarkiske trinitetslæres fokus på den kvalitative forskel mellem Guds nåde og menneskets synd har den etiske indfaldsvinkel til Åbenbaringen fået lov til at sætte dagsordenen for megen teologi. Både Grundtvig og Moltmann synes med rette at være opmærksomme på, at denne moraliserende tendens er uholdbar i en moderne kontekst, hvor autoriteter afskyes og menneskets frihed sættes højt.

I Vestkirken er den enkeltes møde med Gud ikke overraskende ofte blevet beskrevet ved hjælp af en selvbiografisk genre, som måske har sine spæde rødder i Paulus' omvendelse, som den beskrives i 1. Kor. 8 . 
Siden er især Augustins selvbiografiske bog Confessio (ca. 397) blevet en slags inspirationskilde for megen vestkirkelig litteratur og poesi om vejen til religiøs selv-erkendelse ${ }^{39}$. Når teologien degraderes til en beskrivelse af den enkeltes religiøse vækst relateret til den private refleksion eller en mystisk oplevelse sker der en form for psykologisering af teologien, som Grundtvig og Moltmann tager helt afstand fra.

Teologien kan med andre ord siges at have ladet sig diktere af den epistemologiske, etiske og psykologiske interesse, der er fulgt i kølvandet på bl.a. Oplysningstiden, pietismen og eksistentialismen.

Når teologiens område er indskrænket til delaspekter af livet og til et fokus på den enkeltes isolerede forhold til Gud, betyder det, at teologien mister sin kosmiske og ontologiske relevans som fuldgyldig livssandhed. At sekulariseringen dermed ligger lige for døren, det erkender både Grundtvig og Moltmann.

Perichoresis-tankens betydning for antropologien og gudbilledlighedsloeren

Fokuset på fællesskabet frem for på individet forplanter sig naturligt fra teologien til antropologien. Med andre ord bør Grundtvigs og Moltmanns pointering af kristendommens fællesskabsaspekt ses som en antropologisk følge af det perichoresiske personbegreb og talen om et guddommeligt trinitarisk fællesskab. I den forbindelse spiller gudbilledlighedstanken en fremtrædende rolle i begge forfatterskaber.

Hos både Grundtvig og Moltmann relateres gudbilledligheden ikke, som det normalt er tilfældet i vestkirkelig teologi, alene til menneskets indre eller sjæl men i højere grad til det intersubjektive fællesskab i kirke (Grundtvig) og samfund (Moltmann). Dermed lægger de to teologer sig ikke i første omgang op ad Augustins gudbilledlighedslære, der har individet $\mathrm{i}$ centrum. Meget mere driver de på Gregor af Nyssas tanker om fællesskabet som gudbilledlighedens klareste udtryk. Dette kommer tydeligt til udtryk i de to teologers nadvertekster.

\section{Perichoresis-tanken eksemplificeres $i$ de to teologers nadvertekster}

Det perichoresiske virkelighedssyns betydning for såvel teologien som antropologien kommer fint til udtryk i en analyse af de to teologers nadvertekster. Nadverteologiens tale om realpræsens kan således siges at 
udgøre en niche af spørgsmålet om Guds Nærvær. Ikke overraskende gælder det, som vi vil erfare, at såvel Grundtvig som Moltmann besvarer det gængse spørgsmål om realpræsens inden for rammerne af en frelseshistorisk og trinitarisk horisont. Dermed bliver de ikke som normalt i den vestkirkelige tradition stående i en systematisk og kristologisk nadverdiskussion, hvor der primært reflekteres på forholdet mellem det åndelige og det legemlige, dvs. på Kristi tilstedeværelse i elementerne og sakramentet som sådan.

Denne systematiske diskussion har som bekendt siden Reformationen været brændpunktet for de vestkirkelige teologers uenighed ${ }^{40}$ og uheldigvis fastholdt kirkerne $\mathrm{i}$ et fokus på de systematiske forskelle frem for på eventuelle liturgiske og bekendelsesmæssige ligheder, som Grundtvigs og Moltmanns tekster netop kan hjælpe til med at synliggøre.

\section{II: Perichoresis-tanken som den kommer til udtryk i Grundtvigs og Moltmanns nadvertekster}

\section{Grundtvigs nadvertekster}

Det trinitariske Skaberords synlige og usynlige virkelighed

På eminent vis formår Grundtvig ved hjælp af sine tanker om det guddommelige og trinitariske Skaberord, som lød ved Skabelsen, med Inkarnationen og fortsat med Helligånden i menighedens midte, at komme overens med sondringen mellem den immanente og økonomiske trinitetslære uden at eliminere den. Hemmeligheden bag skal findes i hans verbale indfaldsvinkel til det perichoresiske virkelighedssyn. Kernen i Grundtvigs udgave af Perichoresis-tanken er nemlig forestillingen om det trinitariske Skaberord, som han hævder repræsenterer såvel en synlig som en usynlig virkelighed. Grundtvig formår at sammenflette inspirationen fra den eukaristiske trinitetslære med en irenæisk inspireret skabelsesteologi og en luthersk verbalontologisk realpræsenslære ${ }^{41}$. Med andre ord drejer det sig for Grundtvig i nadverspørgsmålet ikke i første omgang om på akademisk vis at udrede forholdet mellem verbum og signum. Langt mere er det det ontologiske tema om liv og død, der er på spil i Grundtvigs nadvertekster ${ }^{42}$.

Guds livgivende Skaberord er ifølge Grundtvig fortsat synligt i verden, fordi det er genkendeligt i gudstjenesten - mest markant ved døbefonten og alterbordet ${ }^{43}$. Her taler Gud fortsat til mennesket og skaber 
gennem Helligånden »Liv og Lys på Jord « ${ }^{44}$. Identifikationen af person og handling er udpræget i Grundtvigs frelseshistoriske trinitetslære.

Grundtvig indsætter Ordets synlighed og genkendelighed i to historiske rum, nemlig i den synlige kirkes diakrone og synkrone identitet ${ }^{45}$. I disse to rum møder vi Ordet som historisk virkelighed.

Kirkens diakrone identitet er kirkehistorien, som placerer menigheden i det kronologiske og historiske forløb. Denne diakrone identitet svarer til Grundtvigs tale om $»$ Kirkens Kraftbevis $\aleph^{46}$ og beror på en tanke om en pneumatologisk historicitet, hvor historien, som vi kender fra Hegels historiesyn, synliggør Åndens Nærvær i verden ${ }^{47}$. Med andre ord beviser Ordets mundtlige overlevering fra de første apostle frem til i dag, at Ånden fortsat er virksom og tilstedeværende i menighedens midte.

Den synkrone identitet derimod går på fællesskabets nutidighed i den fejrende menigheds forsamling og svarer til Grundtvigs tale om søndagen som »Herrens dag « ${ }^{48}$. Her spiller Grundtvigs flittige brug af »frelseshistoriske krydshenvisninger ${ }^{49}$ en vigtig rolle, idet Grundtvigs »liturgiske eksegese ${ }^{50}$ bevirker, at han fokuserer på de bibelske aktørers grundmenneskelige og typologiske træk på tværs af den tidsmæssige kløft mellem teksten og den fejrende menighed.

En lige så vigtig side af Guddomsordet er imidlertid Ordets usynlige virkelighed. Grundtvig fastholder i sine tanker om »Guddomsordet", som »skaber, hvad det nævner « over for det menneskelige og gudbilledlige »Gienlydsord«, som ikke formår at virkeliggøre en performativ og transformativ identitet mellem ord og handling ${ }^{51}$, altid et eskatologisk og usynligt aspekt ved Ordet.

Grundtvigs brug af bordmetaforen i forbindelse med nadveren som et eksempel på Ordets todimensionalitet

Som et direkte eksempel på dybden i Grundtvigs tanke om såvel en synlig som en usynlig side af Guddomsordet kan henvises til hans gennemgående brug af bord-metaforen i forbindelse med nadveren. Det er kendetegnende for Grundtvig, at han i stedet for at tale om dåben og nadveren taler om $»$ Badet og Bordet $\iota^{52}$. Grundtvigs digtning bærer i det hele taget præg af at ville indfælde det kristne budskab i hverdagslivets rammer, hvilket er et naturligt resultat af hans ontologiske fokus. Ved at tale om »Bordet « i stedet for om nadveren spiller Grundtvig på måltidsassociationer $\mathrm{i}$ lighed med Fadervor-bønnens ønske om »det daglige brød« til livets opretholdelse. 
Udover at give associationer til livet her og nu afstedkommer bordmetaforen (foruden en henvisning til Kristi bordfællesskab med de udstødte og med disciplene) en henvisning til det kommende måltid i Guds rige, hvor det opstandne menneske ifølge jødisk tradition skal sidde til bords med patriarkerne ${ }^{53}$. Grundtvig omtaler bl.a. nadveren som $»$ Fuldendelsens Maaltid « ${ }^{54} \mathrm{og}$ skriver, at vi i gudstjenesten făr en forsmag på $»$ Rigets Frugt $\iota^{55}$.

Bordmetaforen beviser altså den dobbelthed og todimensionalitet, som er så kendetegnende for al Grundtvigs digtning. Hans holistiske og verbalontologiske tolkning af sakramentet gennemsyrer alle hans nadvertekster. Dermed overbydes den gængse realpræsentiske spænding mellem legemligt og åndeligt af Guddomsordets dybde forstået som det kontinuerlige princip bag historiens lineære forløb.

Nadverfoellesskabets grund i den trinitariske Guds korlighed:

Det vertikale aspekt

Som et naturligt resultat af sakramentsteologiens holistiske horisont fokuserer Grundtvig med hensyn til nadveren mere på at beskrive en liturgisk enhed end en historisk mangfoldighed. Som Gudsbilledet kvalificeres af fællesskabet mellem de tre personer, således kvalificeres nadvergæsten som person af fællesskabet med Gud og med næsten. Hos den unge Luther finder dette sit udtryk i talen om nadveren som communio Christi et sanctorum ${ }^{56}$. Der er altså tale om et dobbeltsidet fællesskab, der på det vertikale plan har sin grund i det guddommelige trinitariske kærlighedsfællesskab.

Tanken om fællesskabet som den eksistensform, der ligger nadveren nærmest, beror med andre ord på tanken om den åbne trinitet, som vi tidligere så direkte udtalt hos Moltmann. Grundtvigs variant af talen om den åbne trinitet genfindes i fremhævelsen af Guddomsordets integrerende og fællesskabskonstituerende natur:

...Hver en Søndag Guddoms-Ordet,

Skjult i Bad og klart ved Bordet,

Skænker Fællesskab med Gud ${ }^{57}$.

Som tidligere antydet har fællesskabstanken naturligt sin rod i billedet af Gud som Fader og Gud som kærlighed. Grundtvig taler f.eks. i Den Christelige Børneloerdom om »de helliges Fællesskab« i umiddelbar 
forlængelse af en henvisning til »Troen paa Guds Faderlighed, altsaa Kjærlighedens evig Kilde $~^{58}$.

Som en naturlig følge af talen om nadveren som »Fuldendelsens Maaltid $~^{59}$ knytter Grundtvig Fadernavnet og kærligheden til nadverens sakramente. Den paulinske triade: Tro, håb og kærlighed fra 1. Kor. 13.13 genfindes i den liturgiske triade: dåb, Fadervor og nadver. De to triader er dybest set funderet i den guddommelige triade: Helligånd, Søn og Fader. De her refererede treklange er kun et lille udsnit af Grundtvigs imponerende treklangs-systematik, hvis inderste nerve er det perichoresiske virkelighedssyn sat $i$ forhold til det trinitariske Gudsbillede ${ }^{60}$.

At kærlighedstanken først og fremmest knyttes sammen med nadverens sakramente skyldes ikke mindst nadverens anamnetiske aspekt. Nadvermåltidet grunder på korsfæstelsen tolket som den ultimative guddommelige kærlighedsgerning ${ }^{61}$. Derfor taler Grundtvig ikke overraskende om nadveren til »Christi Kiærligheds Ihukommelse ${ }^{62}$.

\section{Den kiastiske struktur i Grundtvigs doksologiske fallesskabstanke}

Fokuset på nadverens fællesskab kendes endvidere fra Paulus. Som Leif Kallesen gør opmærksom på, er 1. Kor. 10.16, med henvisningen til nadvergæstens indlemmelse i »fællesskabet med Kristi legeme og blod «, vel sagtens det nytestamentlige skriftsted om nadveren, som Grundtvig gør mest brug af ${ }^{63}$. Men mens Grundtvig som Paulus understreger menighedsfællesskabets grund i den trinitariske Guds kærligheds-fællesskab, er der en tendens til, at han lægger vægten anderledes end Paulus, når talen falder på dette fællesskabs horisontale implikationer.

Paulus understreger med sin gennemgående parænesiske tone i f.eks. 1. Korintherbrev, at Kristi fællesmåltid med syndere bør være et etisk forbillede for menighedens omgang med hinanden. Grundtvig derimod koncentrerer sig i første omgang om menighedens doksologiske fællesskab. Det særligt grundtvigske ses i hævdelsen af, at det trinitariske fællesskab finder sit udtryk i et doksologisk menighedsfællesskab. Fællesskabstanken făr på denne måde en slags gudbilledlighedsfunktion.

Til grund for tanken om et doksologisk menighedsfællesskab ligger en kiastisk struktur, som primært er foranlediget af Grundtvigs tale om "Skaber-Ordet« over for »Gienlyds-Ordet ${ }^{64}$. Kiasmen viser på én gang Grundtvigs udgangspunkt i den økonomiske trinitet og hans respekt for den immanente trinitet. Den kiastiske struktur ses tydeligt i 5 . vers af salmen: Velsignelse, al jordens $\operatorname{tar}^{65}$. Her hedder det: 
For Guds velsignelse opstig, taksigelse til Himmerig!

Velsignelse da strømmer ned, i skybrud til Guds menighed.

Kristendommens V-struktur, som traditionelt er knyttet til Inkarnationen og menneskets frelse, genfindes altså hos Grundtvig i en verbal og liturgisk udgave. V-bevægelsen gengives her i tanken om Guds vertikale tiltale og menneskets doksologiske svar. Den fælles doksologiske og opadstræbende bevægelse konstituerer det horisontale fællesskab menighedsfællerne imellem. Den græsk-ortodokse teolog Alexander Schmemann skriver meget sigende, at det græske ord for liturgi, leitourgia, "meant an action by which a group of people become something corporately which they had not been as a mere collection of individuals ${ }^{66}$.

Den kiastiske V-struktur er hos Grundtvig med andre ord altid kendetegnet af en form for asymmetri, idet Guddomsordet hos Grundtvig er et stående udtryk for kiasmens udspring i Guds vertikale tiltale af mennesket. Tanken om, at Guddomsord virker genlydsord, er siden blevet udtrykt på en anden, men dog sammenlignelig måde, nemlig i Barths tale om Åbenbaringen med stort og lille $\AA^{67}$.

Grundtvigs liturgiske kiasme, som står helt i kontrast til Barths postkantianske og epistemologiske kiasme, møder vi i en nutidig udgave i metodisten Geoffrey Wainwrights teologi. Han udtrykker det således: $»$ The second-order activity of theology is therefore, at its own level, properly doxological: the theologian is truly theologian when, in his very theologizing, he is listening for the »echo of a voice« and is contributing, even if indirectly, to the human praise of God. It is indeed a traditional diction in Eastern Christianity that the true theologian is the person who prays ${ }^{68}{ }^{2}$. Wainwright har meget sigende givet sit bidrag til en systematisk teologi titlen: Doxology. Hans tale om »a mutual involvement" mellem »worship, doctrine og life ${ }^{69}{ }^{\text {svarer til Grundtvigs doksologiske }}$ teologi og eukaristiske trinitetslære. Begge teologer kan dermed siges at ville forsvare den oldkristne sammenføjning af bønnens og troens lov (lex orandi lex credendi $)^{70}$. 
Det doksologiske fallesskabs økumeniske, globale og kosmiske rakkevidde

I Grundtvigs antropologi sker der en betydelig udvidelse af privatsfæren, idet det enkelte menneske på en måde omgives af fire koncentriske cirkler, hvis fælles centrum er det trinitariske fællesskab. Den første cirkel er det ovenfor skitserede doksologiske menighedsfællesskab. Den næste cirkel er det økumeniske fællesskab ${ }^{71}$ med tilsidesættelsen af enhver esoterisk ecclesiologi. Den tredje cirkel er det globale fællesskab ${ }^{72}$ relateret til Grundtvigs tanker om hele verdens fællesskab med Skaberen. Den sidste cirkel er det kosmiske fællesskab med englene ${ }^{73}$. Denne sidste understregning af lovsangens kosmiske aspekt, som sker på bekostning af et mere ecclesiologisk fokus, minder lidt om Moltmanns doksologiske fællesskabstanke.

\section{Den eukaristiske nadverlores anamnetiske aspekt}

En variant af tanken om det doksologiske menighedsfællesskab findes udtrykt i talen om en eukaristisk offertanke.

Ved siden af diskussionen om realpræsens har det andet mest diskuterede tema i Vestkirken i forbindelse med nadverlæren velsagtens været diskussionen om nadverens forhold til offermotivet.

Talen om et offermotiv er en direkte følge af den kristne påskes sammenfald med det jødiske påskemåltid. Påskelammets slagtning i templet falder tidsmæssigt sammen med den kristne nadverfejrings historiske indstiftelse. Endvidere kendes offertanken fra Deuterojesajas' tale om Herrens lidende tjener, hvis liv blev bragt som skyldoffer (Es. 53. 10). I Det Nye Testamente møder vi især offertanken og Deuterojesaja i Johannes-evangeliets tale om Kristi korsdød.

Ordet 'offer' făr hos Grundtvig i forbindelse med nadveren en atypisk positiv betydning. Mens ordet 'offer' normalt bringer associationer til død og ensom gudsforladthed, knyttes det i Grundtvigs salmer tæt sammen med en tale om $» N a d v e r e n s$ glæde $\aleph^{74}$ og tanken om det doksologiske menighedsfællesskab. Dermed kan Grundtvig siges at repræsentere den eukaristiske offertanke. Den eukaristiske offertanke møder vi f.eks. i en af hans smukkeste salmer: I al sin glans nu stråler solen, hvor han i relation til nadveren taler om »takkesangens offerskål ${ }^{75}$.

I den forbindelse er det værd at inddrage Erik Kyndals bog, Nadverlare og Nadverfoellesskab. Det er Kyndals force, at han ønsker den 
eukaristiske offertanke genindført i forbindelse med nadveren. Kyndal peger på det eukaristiske nadversyns historiske baggrund i ritualet til det jødiske påskemåltid. Her bedes der i forbindelse med velsignelsens bæger en stor takkebøn ${ }^{76}$. En variation af denne takkebøn udgjorde en vigtig del af nadverritualet $i$ Oldkirken, men er efter Reformationen faldet bort. Nu møder vi den på ny i Grundtvigs salmer. Her fremhæver Kyndal især nr. 54 i $D D S^{77}$, hvor det eukaristiske nadversyn klart præciseres:

Lov og tak og evig ære, ofrer vi dig, Herre sød, Jesus Krist, Guds Søn den kære, for dit liv og for din død.

Også den græsk-ortodokse teolog A. Schmemann beklager, at dette moment efter opgøret med den katolske messeoffertanke er faldet bort i den vestkirkelige nadverfejring. I Østkirken derimod er det bevaret og udgør endog en af grundstenene i nadverlæren ${ }^{78}$.

Både Schmemann og Grundtvig fremhæver i den forbindelse Kristus som et eukaristisk forbillede. I salmen Jeg veed et lille Himmerig, taler Grundtvig f.eks. med en henvisning til Getsemane-scenen om, at Kristus endog i denne time hviskede: »Lovet være Gud ${ }^{79}$.

Schmemann præciserer eksplicit, at den eukaristiske offertanke akkurat som den doksologiske menighedstanke har sin grund i anamnesen og Kristi offer, og taler om nadveren som stedet, hvor vi ofrer os selv til Gud »in Christ in remembrance of him... ${ }^{80}$. Se desuden den før citerede salme af Grundtvig, hvor henvisningen til »takkesangens offerskål« senere indholdsbestemmes som »Jesus-navnets offerskål ${ }^{81}$. Endvidere skriver Grundtvig, at det eukaristiske offer er en »Gienlyd af Kristi Offer«.

Det eukaristiske og anamnetiske aspekt er vigtigt for, at offertanken ikke ender i pelagianisme. Det eukaristiske offer bør ikke identificeres med det katolske misbrug i form af messeofferet, som den katolske kirke ifølge G. Wainwright i postreformatorisk ånd selv har sat sig ud over ${ }^{82}$. Som Wainwright skriver, er der altså ikke tale om en gentagelse af Golgata-offeret, men om en anråbelse af det $^{83}$. Mennesket kan ikke udføre en ny soningshandling. Det kan alene frembære et mundtligt og eksistentielt svar på Kristi handling. Som allerede antydet bestemmes nemlig alene de tre guddommelige personers væren af en performativ identifikation af ord og gerning. 
Det anamnetiske aspekt afholder endvidere den eukaristiske offertanke fra at ende $\mathrm{i}$ en opadstræbende grundløs mysticisme og en ren theologia gloriae. Lovsangsofferets grund er den historiske indstiftelse af den levende Kristus, »i den nat, da han blev forrådt.." (1. Kor. 11.23).

\section{Den eukaristiske nadverlores epiklesiske aspekt}

Det eukaristiske nadversyns anamnetiske henvisning til Jesu Kristi historiske indstiftelse af nadveren giver kun mening for os i dag via troen på Kristi fortsatte Nærvær i menigheden. Dette Nærvær relaterer Grundtvig til Helligåndens gerning, idet hans nadverteologi eksemplificerer den tætte sammenbinding af kristologi og pneumatologi, som vi så udtrykt $\mathrm{i}$ den anden åndstradition.

NårHelligånden virker Kristi fortsatte Nærvær, tilføres gudstjenesten naturligt et epiklesisk aspekt, som meget klart kommer til udtryk i den epiklesiske salme: $O$ Hellig-Aand! som Pindse-Dag... Her bedes der i 3 . strofe om Helligåndens (»Alvirkerens «) bistand i menighedens glade lovsang af treenigheden:

Giv Ordet Liv og Kraft og Fynd, I Tungens Raab og Hjertets Nyn,

Saa glade vi tilbede

Gud-Fader og hans kiære Søn,

Og Dig, vort Pant, vor store Løn,

Alvirkeren hernede... ${ }^{84}$.

Citatet tydeliggør, hvordan udgangspunktet for Grundtvigs trinitariske teologi, i lighed med den eukaristiske trinitetsmodel, bliver Helligåndens aktuelle virke i menighedens forsamling.

Det epiklesiske tema er endnu en reminiscens fra den græsk-ortodokse liturgi.

\section{Grundtvig og den tiltagende tendens til en foelles økumenisk enighed}

Som det er fremgået af gennemgangen af Grundtvigs nadversyn har det i overvejende grad været frugtbart at sammenstille ham med personer, der står udenfor den vestkirkelige nadverdiskussions tendens til at låse sig fast i et akademisk tovtrækkeri i lyset af de reformatoriske splittelser 
mellem et symbolsk og substansontologisk nadversyn. Grundtvigs nadverlære har, som det er fremgået, foruden ligheden med Luther, mange lighedspunkter med såvel den græsk-ortodokse teolog Schmemanns nadverlære som med metodisten Wainwrights teologi. Fælles for dem alle er, at de kan siges at repræsentere en praktisk liturgisk og eukaristisk tilgang til nadverlæren, som måske kan vise sig at være svaret på, hvordan man i fremtiden skal overvinde systematisk begrebsrytteri og økumenisk uenighed.

Der er allerede taget store tiltag i retningen af en mere liturgisk og eukaristisk tilgang til nadverspørgsmålet. Den økumeniske dialog, som bl.a. føres gennem Faith and Order ${ }^{85}$, synes især i nadverspørgsmålet at have gjort betydelige økumeniske landvindinger - ikke mindst hvad angår skismaet mellem Øst- og Vest-kirken. De seneste tiltag viser en stigende tillid til, at tanken om den eukaristiske nadverlære i dens relation til den eukaristiske trinitetsmodel måske kan nedbryde muren mellem de stridende kirker. I nadveren anskueliggøres og klarlægges trinitetsspørgsmålet på en håndgribelig måde. Med andre ord er nadverdiskussionen et godt og konkret udgangspunkt for den økumeniske dialog.

En lang række af Grundtvigs tanker kan f.eks. genfindes i Limaerklæringens nadverafsnit $(1982)^{86}$, der ligeledes bærer præg af en græskortodoks indflydelse. Lima-erklæringen beskæftiger sig heller ikke i første omgang med realpræsenslæren og sonoffertanken. Altoverskyggende er derimod græske begreber som eukaristi, anamnese og epiklese. Disse begreber viste sig at være nøglebegreber i Grundtvigs nadverlære.

Dermed har Grundtvigs nadvertekster bevist deres potentiale som en frugtbar inspirationskilde for den videre økumeniske debat.

\section{Moltmanns nadvertekster}

Moltmanns alternativ til sondringen mellem den immanente og økonomiske trinitetslære har for mig at se ikke samme gennemslagskraft som Grundtvigs just gennemgåede alternativ. Ikke desto mindre har Moltmann set ensidigheden ved den monarkiske tradition. Han er derfor en god samtalepartner, når det gælder om at indkredse Grundtvigs fortsatte aktualitet på den økumeniske scene. Blikket rettes nu mod Moltmanns nadvertekster, der tjener som et eksempel på en nulevende teologs brug af et perichoresisk og trinitarisk virkelighedssyn. 
Moltmanns teologi er først og fremmest et opgør med et sekulært historiesyn og en lineær tidsopfattelse. Han kredser gang på gang om den værdiladning af nutiden, der sker med Kristi opstandelse, hvor Gud lover mennesket en frelseshistorisk horisont. Hans historiske og temporale indfaldsvinkel til teologien kan på mange måder siges at være en kristen bearbejdelse af det jødiske forjættelses-opfyldelses skema, hvor især beretningen om Exodus spiller en vigtig rolle. Når Moltmann taler om, at mennesket lever en eksileksistens i en simultanpræsentisk virkelighed $^{87}$, hvor nutiden er spændt ud mellem erindringen om Guds fortidige handlinger, dvs. Skabelsen og Åbenbaringen på den ene side, og håbet om Fuldendelsen og den guddommelige Nærværelse som Guds kommende handling på den anden side, giver det associationer til den gammeltestamentlige Promissio-bevidsthed. Moltmanns Promissio-bevidsthed skinner ikke mindst igennem i hans nadvertekster.

Overføres Moltmanns frelseshistoriske tre-tidsskema ${ }^{88}$ nemlig på nadveren, bliver der, som Moltmann selv gør opmærksom på, $i$ thomistisk ånd tale om nadveren som et "signum rememoritavum " (det anamnetiske element med vægt på Kristi kors og den økonomiske trinitet) et »signum prognosticon« (det eskatologiske element med vægt på Kristi opstandelse, det evige liv og den immanente trinitet) og et "signum demonstrativum " (en slags realpræsentisk element med vægt på Helligåndens eskatologiske Nærvær og nutidens simultanpræsentiske tid) ${ }^{89}$.

Vigtig for Moltmann bliver især talen om nadveren som et »signum demonstrativum«, der hænger nøje sammen med hans tolkning af Kristushistorien som et guddommeligt løfte (Promissio) givet med Helligåndens Nærvær i Kristus-begivenheden. Med andre ord bliver nadveren et eksempel på, hvordan Moltmann anvender det blochske ${ }^{90}$ og jødiske tretids-skema $\mathrm{i}$ ånds-kristologiens tjeneste. Foruden inspirationen fra Ernst Bloch og Det Gamle Testamente støtter Moltmanns proleptiske realpræsenslære sig især op ad nadvertraditionen fra Calvin og Zwingli. Som bekendt kaldes denne tradition for den symbolske eller spirituelle nadverlære, fordi den afstår fra at tale om en substansontologisk forening af Kristi legeme og blod og nadverens elementer. Derimod fastholder denne tradition, som Moltmann, en grad af guddommeligt substantielt fravær i sakramenterne.

Når sakramenterne primært tjener som tids- og historie-tegn $n^{91}$, mister de betydning og bliver sekundære udtryk. Moltmanns ecclesiologi står 
derfor i fare for at bevirke en slags afliturgisering af kristendommen, som måske nok er moderne, men som ikke desto mindre efterlader kristenlivet $i$ et rodløst og traditionsforladt tomrum, hvor kirkehistorien og det liturgiske rum drukner i universalhistoriske dybder. Det er karakteristisk for Moltmann, at han grundet sin eskatologiske og universalhistoriske bevidsthed endog i sin mest ecclesiologiske bog, Kirche in der Kraft des Geistes leder ordet sakramente tilbage til dets oprindelige aliturgiske betydning. Han skriver: "Sofern mit sacramantum in den lateinischen Übersetzungen das griechische Wort $\mu \cup \sigma \tau$ ń $\llcorner$ ८ $\vee$ wiedergegeben wird, sind nicht Taufe und Herrenmahl gemeint, sondern das eschatologische Geheimnis Gottes «"2

Dog skal det siges, at Moltmann senere i sit forfatterskab, dvs. fra 1980 'erne og frem, nuancerer sin tidlige ensidigt temporale og eskatologiske tilgang til trinitetslæren ${ }^{93}$. Moltmann fokuserer nu mere på Helligåndens nyskabende virkelighed og taler om »die trinitarische Gemeinschaftserfahrung ${ }^{94}$. Dermed kommer fællesskabs-tanken ligeledes til at spille en vigtig rolle for Moltmann, men til trods for, at han selv betegner sin senere teologi som »eine Theologie des Raumes«, formår Moltmann som Grundtvig aldrig at skabe et egentligt realpræsentisk rum for menneskets deltagelse i Gudsnærværet. Han spænder rummet ud til bristepunktet i sit historiske og eskatologiske fokus. Det tætteste han nogen sinde kommer på en slags rumtænkning er hans brug af det perichoresiske virkelighedssyn i forbindelse med talen om en doksologisk trinitetslære.

Fœllesskabstanke og gudbilledlighedsloere: "Die Trinität ist unser Sozialprogramm ${ }^{95}$

Den tyske teolog Markus Dröge skriver meget sigende, at det er Moltmanns hensigt, at den personlige forbindelse mellem de tre artikler $i$ Trosbekendelsen skal genspejles i kirkens historiske skikkelse ${ }^{96}$. Ved dermed at fremhæve det perichoresiske personbegreb som et antropologisk ideal viser Moltmann, at også han har ladet sig inspirere af den græske communio-tanke. Moltmann hævder i ETD, at det trinitariske Gudsbillede befrier det individualiserede menneske fra isolation ${ }^{97}$. I det hele taget beskriver han, som Grundtvig, kristenlivet og gudsforholdet under fællesskabets fortegn. Gang på gang reflekterer han over trinitetslærens offentlige og sociale relevans. 
Ifølge Moltmann finder det trinitariske gudsbillede sit antropologiske udtryk i et socialt fællesskab, hvor frelseshistorien udgør indholdet i den intersubjektive relation. Perichoresis-tanken, der gør op med et hierarki mellem de tre artikler i Trosbekendelsen, afføder naturligt en tanke om social lighed. Moltmanns teologi indeholder dermed et parænesisk element. Dette ses f.eks. i hans talrige henvisninger til nadverens oprindelse ikke alene i Kristi sidste måltid med disciplene, men i alle Kristi måltidsfællesskaber med toldere, syndere og udstødte. For Moltmann bør kirken fortsat være de marginaliseredes kirke. Dette fokus på de svages ret kan bl.a. ses som et naturligt resultat af hans kritiske refleksion over Rigskirkens samarbejde med den stærke nazimagt under 2. Verdenskrig.

Tanken om kirken som et fællesskab hører tæt sammen med Moltmanns tanke om imago trinitatis ${ }^{98}$. Det menneskelige fællesskab kvalificeres også hos Moltmann af det inkluderende i det trinitariske fællesskab, tidligere udtrykt i termen »die offene Trinität«, og i tanken om Gud som kærlighed. Mens gudbilledligheden hos Grundtvig knyttedes til talen om det liturgiske og eukaristiske fællesskab, knyttes den altså hos Moltmann primært til talen om et socialt og frelseshistorisk fællesskab $^{99}$.

Moltmann griber i sin tanke om triniteten som et socialt program tilbage til Gregor af Nyssas gudbilledlighedslære. Gregor af Nyssa taler om den trinitariske familiestruktur med far, mor og børn, som det sociale udtryk for triniteten. Moltmann skriver med henvisning til Gregor: »Wenn wir den ganzen Menschen, Mann und Frau und Kind, als Ebenbild Gottes verstehen, dann verstehen wir die wirkliche menschliche Gemeinschaft als Ebenbild des dreieinigen Gottes, nicht nur als Ebenbild seiner äusseren Herrschaft, sondern auch als Ebenbild seines inneren Wesens ${ }^{100}$.

Dette svarer til, at Moltmann fremhæver det perichoresiske personbegreb og den doksologiske trinitet som idealet på det sande messianske og eukaristiske fællesskab i og uden for kirken.

\section{Et messiansk fcellesskab}

Moltmann refererer i 1975 i $K K G$ til kirken som »et messiansk fællesskab « (»eine messianische Gemeinschaft «) ${ }^{101}$. Med et messiansk fællesskab mener han et fællesskab, der, grundet et perichoresisk virkelighedssyn, afspejler en levevis, der knytter til ved Kristushistorien udlagt som Åndshistorie og Opstandelsesproklamation. Talen om et messiansk 
fællesskab er med andre ord funderet i Moltmanns pneumatologiske kristologi og brug af anden åndstradition. En messiansk levestil betyder kort fortalt at turde leve på Guds løfter i Helligåndens Nærvær og som Kristus åbne sig for Guds fremtid.

Idealet for det messianske fællesskab bliver derfor på mange måder Jesu Kristi liv. Især fremhæver Moltmann ikke overraskende Kristi åbne holdning til Guds rige som et prisværdigt livsideal. Der er med andre ord tale om en slags imago Christi med Markus 1.15 som eksegetisk nøglested.

For Moltmann betegner det messianske det dynamiske og fremtidsorienterede. Som Markusevangeliets fortælling drives frem mod opstandelsens klarsyn, hvor dét skal åbenbares, som for disciplene kun fremstår som »messiashemmeligheder«, bevæger den kristne sig frem mod det Gudsrige, der nu alene er til stede som en mulighed udsprunget af evangeliets guddommelige Promissio. Der er noget profetisk over messianismen i Moltmanns terminologi, som unægteligt driver på jødisk gods.

\section{Et eukaristisk foellesskab og en eukaristisk offertanke}

Som E. Kyndal gør opmærksom på, taler Moltmann senere i sit forfatterskab udover det messianske fællesskab oftere og oftere om et eukaristisk og doksologisk fællesskab ${ }^{102}$. Dette fællesskab afspejler ikke (som Moltmanns tale om et messiansk fællesskab) så meget hans samfundskritiske engagement, der primært er foranlediget af efterkrigstidens og 60'ernes og 70'ernes sociale og politiske problemstillinger. Derimod er talen om et eukaristisk fællesskab i højere grad foranlediget af Moltmanns teologiske kritik rettet mod den ensidige fremhævelse af kristologien på pneumatologiens bekostning. Dermed er det eukaristiske fællesskab relateret til hans interesse for en doksologisk trinitetslære.

Det messianske og eukaristiske fællesskab bør ikke ses som to separate fællesskaber. De er begge et resultat af Moltmanns frelseshistoriske og eskatologiske indfaldsvinkel til Trinitetslæren. Forskellen mellem de to fællesskaber understreger højst den accentforskydning i Moltmanns teologiske interesse, som blev antydet ovenfor.

Talen om et eukaristisk fællesskab understreger, at heller ikke Moltmann har meget til overs for nadveren udlagt som en offerhandling. Moltmann skriver: »Sein Tod ist eucharistisch zu verstehen, und die Eucharistie von seinem Tode her ${ }^{103}$. Også han tilslutter sig altså tanken om nadveren som et eukaristisk takkeoffer, idet han taler om, at menigheden 
her bekender den opstandnes Nærvær i en slags eskatologisk glædesrus. Han kalder selv nadveren et »takkeoffermåltid « (»ein Dankopfermahl«) under henvisning til dens analogi med det jødiske takkeoffer, der blev bragt som svar på Guds frelsende gerninger ${ }^{104}$.

Også hos Moltmann er mennesket altså henvist på bekendelsen som et svar på den treenige Guds kærlighed.

\section{Teologiens to genrer}

Teologien og bekendelsen har hos Moltmann to skikkelser. Det drejer sig om henholdsvis et narrativt og et doksologisk udtryk. Det første relaterer sig til den økonomiske trinitetslære - det andet til den immanente trinitetslære. Moltmann skriver selv om de to genrer: »Dabei ist zu unterscheiden zwischen der geschichtlichen Kontingenz in der trinitarischen Geschichte, die zum Erzählen nötigt, und der Ursprungskontingenz in der Trinität selbst, die zum Lobpreis nötigt ${ }^{105}$.

Talen om teologiens narrative eller doksologiske udtryk bør ligeledes sættes i relation til den omtalte accentforskydning i Moltmanns teologi, som foranlediger, at han mere og mere understreger teologiens doksologiske karakter.

\section{Det anamnetiske aspekt afføder en narrativ genre}

Som det er fremgået, er det kendetegnende for Moltmann, at han tager sit udgangspunkt i evangeliet tolket som historiens Historie (dvs. i evangeliets frelseshistoriske betydning for den kronologiske historie) ${ }^{106} i$ stedet for i evangeliets liturgiske Sitz im Leben. Salmer og prædikener bliver derfor aldrig Moltmanns foretrukne genre. Det gør derimod en narrativ genre, der fint afspejler hans frelseshistoriske eksegese. Det narrative udtryk er en naturlig følge af arbejdet med den økonomiske trinitetslære, idet det relaterer sig til erindringen om Guds frelsende handling. Mennesket indlemmes ved brugen af fortællingens konkrete sprog ifølge Moltmann i historiens Historie. Det samme engagement ville ikke gøre sig gældende ved brugen af et abstrakt videnskabeligt sprog, fordi et sådant sprog afspejler en rationel objektivitet (jf. talen om theologia prima over for theologia secunda).

Moltmann præsterer en forfriskende billedrig og narrativ tilgang til det systematiske stof, som måske kan kritiseres for mangel på objektiv 
faglighed og streng eksegetisk korrekthed ${ }^{107}$, men som ikke desto mindre fænger på grund af sit engagerede islæt. I sin systematiske tilgang til teksten vil Moltmann ikke som den eksegetiske teolog se bort fra læserens kontekst, forudfattede holdninger og sindelag. Moltmann betegner meget sigende teksten som en samtalepartner i stedet for som et historisk kritisk objekt og taler om at bygge bro mellem teksten og læserens nutidige virkelighed. Grundpillerne i Moltmanns hermeneutiske bro bliver den narrative genre.

Moltmanns samfundsorienterede teologi, som skydes i gang med Anden Verdenskrigs påtrængende teodicé-spørgsmål, kan hævdes at tage konsekvensen af kristendommens nutidige sekulære kontekst. Dette må siges at være en styrke - med mindre kristendommen derved gør for mange indrømmelser, således at det kristne budskab relativeres i skyggen af samfundets tendens til værdiløshed og autoritetsafsky. Spørgsmålet er, om Moltmanns teologi ikke indeholder den fare.

\section{Det eskatologiske aspekt afføder en doksologisk genre}

Når theologia crucis og theologia gloriae knyttes så tæt sammen, som det er tilfældet i Moltmanns »Geist-Christologie ${ }^{108}{ }^{108}$, kan teologien som sagt ikke nøjes med det narrative udtryk. I modsætning til fortællingens anamnetiske aspekt, som Moltmann, som før nævnt, tilskriver den økonomiske trinitet, har mennesket kun lovprisningens mulighed, når blikket rettes mod det guddommelige overskud i den immanente trinitet. Til den eskatologiske og epiklesiske side af virkeligheden svarer med andre ord doksologien som genre.

Mens fortællingen om den økonomiske trinitet gør brug af menneskets eget tidsperspektiv, knytter lovprisningen til ved evighedens ahistoriske og irrationelle perspektiv. Teologen kan derfor ifølge Moltmann ikke forstå, men må alene undres og glædes over den immanente trinitet $^{109}$. Dette svarer til Grundtvigs fremhævelse af barnets undren og kvindehjertets åbenhed som troens ideelle form ${ }^{110}$.

Set i lyset af dette eskatologiske evighedsperspektiv kan den doksologiske genre siges at ville foregribe menneskets endelige doksologiske participation i det evige trinitariske kærlighedsfællesskab. Tanken om, at den doksologiske genre bør sættes i relation til den endelige kosmiske lovsang i Guds rige, så vi tidligere udfoldet i Grundtvigs salmer.

Den doksologiske genre tilstræber med andre ord at forblive tro mod indholdet af den doksologiske trinitetslære. 
Moltmann mener, at han overbyder såvel den monarkiske som eukaristiske trinitetslære i sin egen doksologiske trinitetsmodel. Den doksologiske trinitetslære er Moltmanns vigtigste forsøg på at udfolde det perichoresiske personbegreb.

Talen om en doksologisk trinitetsmodel hænger naturligt sammen med Moltmanns stigende fremhævelse af pneumatologien. Selv skriver han, at Helligåndens nutidighed som »Gegenwart « i menighedens midte siden i den doksologiske trinitet skal blive et personligt »Gegenüber « ${ }^{111}$. Et andet sted indkredser han kernen i den doksologiske trinitetslære ved hjælp af en sekvens fra Nicæno Constantinopolitanum: »Helligånden

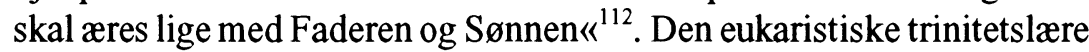
udvides dermed til den doksologiske trinitetslære, som Moltmann altså betragter som trinitetslærens krone.

Det er ikke så mærkeligt, at den engelske ekseget Richard Bauckham mener, at Moltmann med den doksologiske trinitetslære overtræder de grænser, som han selv tidligere har stillet op for den teologiske erkendelse $^{113}$. Nok mediterer Moltmann i denne model over den immanente trinitet, men det synes væsentligt at ihukomme, at det netop ikke er i et forsøg på at indfange den. Den immanente trinitet forbliver for Moltmann altid en eskatologisk størrelse ${ }^{114}$.

\section{En konkluderende kommentar til Moltmanns doksologiske trinitetslaere}

Moltmanns tripolære historieskema, som viste sig at udgøre en vigtig ramme omkring såvel hans perichoresiske virkelighedssyn som hans nadverteologi, minder på mange måder om Hegels tale om tese - antitese - syntese. Oversat til moltmannske termer betyder det, som vi har set, at nadveren er spændt ud mellem fortid og fremtid dvs. mellem anamnetisk-kristologisk erindring og eskatologisk-pneumatologisk håb mellem legemligt og åndeligt mellem historisk og guddommeligt mellem kors og opstandelse mellem den økonomiske og immanente trinitetslære.

Nadveren bliver dermed et eksempel på et slags gennemgående dobbelt bogholderi i Moltmanns teologi. Det dobbelte bogholderi udspringer især af Moltmanns udgave af den anden åndstradition, idet der hos Moltmann bliver tale om et slags evangelisk dobbeltspor. Moltmann forsøger hele tiden den balancekunst det er, at ville tage sit udgangspunkt i Gud i historien gennem Kristi kors uden at underkende Guds frelses- 
historiske overskud i Kristi opstandelse. Dermed ender han med to historier og to Guder ${ }^{115}$. Reminiscenser af dette så vi bl.a. komme til udtryk i hans tale om teologiens to genrer. Som $\mathrm{H}$. Thomsen så rammende konkluderer, skyldes Moltmanns dobbelte bogholderi, at han »inkonsekvent undlader at tænke den immanente og økonomiske trinitet virkelig sammen som den mulighedsbetingende forudsætnings saglige primat og den betingede aktualiserings sagligt sekundære udtryk « $^{116}$. Som vi har set, er det syntetiske element i Moltmanns teologi forstået som det sted, hvor den immanente og økonomiske trinitet mødes, nemlig alene til stede i nutiden som en eskatologisk-pneumatologisk realitet. Som et realpræsentisk og rumligt aspekt finder det syntetiske element først sit egentlige udtryk i Gudsrigets Perichoresis og doksologiske trinitet. Her kan det dobbelte bogholderi på en måde siges at blive forløst.

Moltmanns dobbelte bogholderi hænger for mig at se uløseligt sammen med hans polemiske tone over for især Barth og Bultmann. Der er i højere grad tale om en kritisk replik end om et direkte brud med den reformerte og dialektiske tradition, som Moltmanns teologi selv er et produkt af. Moltmanns kritik af, hvad han læser som Barths monarkiske teologi og hans transcendentale eskatologi, medfører, at han nedprioriterer Åbenbarings-aspektet og talen om Guds Ord som et rent vertikalt møde mellem Gud og mennesket. Hans kritik af Bultmanns eksistentialisme og individualistiske og præsentiske eskatologi foranlediger, som vi har set, at Moltmann betoner fællesskabet og det futuriske element.

H. Thomsens efterlysning af et statisk element i Moltmanns teologi preller altså af på Moltmann, hvis hensigt det netop er at løsrive teologien fra enhver snærende ahistorisk grund. Moltmann frygter Åbenbaringsteologiens fokus på det vertikale og statiske møde mellem Gud og mennesket, fordi han som sagt ser dette fokus som en skjult teologisk transcendering af det menneskelige subjekt, der gør, at Gud imod hensigten mister den frihed og det overskud, som ellers er den dialektiske teologis force.

Moltmann bevarer, som det kom til udtryk i hans nadvertekster, noget teleologisk og hegelsk i sit historiesyn, som er Åbenbaringsteologien helt fremmed. Han kan i en eller anden grad siges at indoptage en slags evolutionær og naturvidenskabelig tanke om en vis uforudsigelighed i naturens love. Dette betyder, som vi har set, at nutiden kvalificeres af fremtiden beskrevet ved hjælp af mulighedernes og håbets modus. Dermed skabes den "processualisering $" 117$ og foranderlighed i gudsbilledet, som har vist sig at være så kendetegnende for Moltmanns 
trinitetslære. Spørgsmålet er imidlertid, om dette processualiserings-element i Moltmanns teologi imod hensigten fratager mennesket en reel mulighed for at participere i den perichoresiske virkelighed?

\section{Forskelle mellem Grundtvig og Moltmann}

Grundtvigs og Moltmanns divergerende syn på forholdet mellem kristologi og pneumatologi

Som det er fremgået, har de to teologers forsøg på at nedtone sondringen mellem den økonomiske og immanente trinitetslære ikke mindst noget at gøre med deres tolkning af forholdet mellem de to sidste trosartikler og deres for vestkirkelige teologer særlige årvågenhed overfor Helligåndens ligeværd med Faderen og Sønnen. Kendetegnende er det imidlertid, at de to teologers fælles ånds-kristologiske skæringspunkt ligeledes bliver det punkt, der bedst markerer deres forskelle.

For Grundtvig er Kristus det inkarnerede Skaberord. Dette ser han især komme til udtryk gennem Kristi imperativiske befalingsord, som betegner Åndens virke gennem Jesus Kristus ${ }^{118}$. Grundtvig fremhæver altså Kristi performative verbalhandling som stedet for Helligåndens Nærvær. For Moltmann derimod bliver det Kristi holdning til Gudsriget, der står i centrum. Her er der ikke tale om en verbal identifikation med pile bagud, men om en fremadrettet åndelig identifikation. Kristi liv er idealet på et liv levet i Guds forfrakommende virkelighed, hvilket for Moltmann vil sige et liv oplyst af Helligåndens nyskabende Nærvær.

Grundtvigs og Moltmanns divergerende syn på Helligånden: Grundtvigs lutherske arv over for Moltmanns calvinske arv

De to forskellige syn på Helligåndens Nærvær i Kristusbegivenheden afspejler naturligt to forskellige pneumatologier. Her bør kernen i sammenligningen mellem de to teologer findes. Det er Grundtvigs særkende, at han fastholder Skaberordets kontinuitet, idet han knytter Skaberordet sammen med de fra Kristi mund overleverede tiltaleord, som vi fortsat hører og genkender i gudstjenesten. Her møder vi Helligåndens skaberkraft i dag. Ovenfor kom Grundtvigs kontinuitetstanke til udtryk i talen om »Kirkens Kraftbevis«. Moltmann derimod underkaster Helligånden en historisk processualisering, som vi har set komme til udtryk i tanken 
om Kristus-begivenhedens fortsatte rækkevidde som nutidig Promissio. Nærværelsen kan i de to teologier dermed groft skitseret siges at tilhøre henholdsvis en rumlig-liturgisk og en historisk-eskatologisk kategori.

De to forskellige syn på den pneumatologiske Nærværelse afspejler, at Grundtvig og Moltmann står dybt forankret i hver deres gren af den vestkirkelige tradition. Vi har i det foregående set Moltmanns calvinske inspiration give sig udslag $i$ en calvinsk inspireret nadverlære. Grundtvig derimod så vi knytte til ved Luthers verbale realpræsenslære. Gennemgangen af de to teologers nadversyn har altså vist, hvorledes temaet om et trinitarisk Nærvær, som unægteligt driver på østkirkeligt gods, kommer til udtryk hos såvel en reformert som en luthersk teolog.

Grundtvigs og Moltmanns forskellige brug af den grask-ortodokse tradition

Mens Grundtvig, som vi har set, bevarer den græske kirkes liturgiske og sakramentale bevidsthed, bruger Moltmann den græske kirkes trinitariske nadversyn som et redskab i en større sags tjeneste, nemlig som et springbræt til sin egen doksologiske trinitetslære. Han suger med andre ord ånds-kristologien og den eukaristiske trinitetslære ud af den i Østkirken oprindeligt sakramentale sammenhæng og indsætter den i sit eget frelseshistoriske og eskatologiske univers. Han bruger altså den liturgiske teologi i den systematiske teologis tjeneste. Grundtvig derimod bevarer den

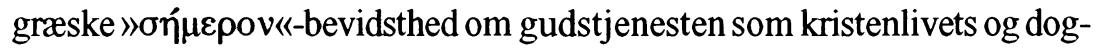
matikkens højborg.

En afsluttende og konkluderende kommentar til Grundtvigs og Moltmanns divergerende tolkninger af forholdet mellem Skabelse, Abenbaring og Norvarelse

\section{Grundtvigs styrke og Moltmanns svaghed}

Det er Grundtvigs styrke, at han på én gang med sin inddragelse af et perichoresisk og trinitarisk virkelighedssyn formår at gøre op med et forældet autoritativt og statisk gudsbillede, samtidig med at han bevarer en virkelig kerne for mødet mellem den immanente og økonomiske trinitet i tanken om »det levende Guddoms-Ord" som Perichoresens omdrejningspunkt. Hans sammenknytning af trinitetslære og Skaberord leverer 
en enestående mulighed for en levende udfoldelse af forholdet mellem den immanente og økonomiske trinitet. Dette skyldes ikke mindst, at den skabelsesteologiske og verbal-ontologiske indfaldsvinkel til den trinitariske teologi besidder en særlig evne til at tænke Helligåndens gerning lige med Faderens og Sønnens. Med andre ord må man samtykke, når Morten Mortensen skriver, at Grundtvig formår at gøre pneumatologien forståelig og vedkommende ${ }^{119}$. Den trinitariske teologi bliver nemlig vedkommende i det øjeblik, pneumatologien ikke alene relateres til en futurisk og proleptisk men ligeledes til en præsentisk virkelighed - dvs. i det øjeblik, Helligånden som person i lighed med Faderen og Sønnen sættes i forbindelse med en reel historisk handling. Hvis den trinitariske teologi skal overvinde Vestkirkens ufrugtbare sondring mellem universitet og kirke, kræver det især, at pneumatologien gøres mere forståelig og mindre spekulativ, abstrakt og mystisk, end det normalt er kutyme på vore breddegrader.

Styrken i Grundtvigs trinitariske Ordteologi kan vendes til en svaghed i Moltmanns trinitariske Håbsteologi. Når Helligåndens reelle ligeværd med Faderen og Sønnen, som det er tilfældet i Moltmanns doksologiske trinitetslære, rangerer under en eskatologisk og teleologisk kategori, bevirker det, at den immanente og økonomiske trinitetslære, på trods af Moltmanns ønske om en slags teologisk sameksistens, aldrig virkelig mødes. Dermed vanskeliggøres menneskets reelle deltagelse i det trinitariske og perichoresiske fællesskab, og man får følelsen af at eksistere i en slags »skizofren« virkelighed spændt ud mellem Åbenbaringen og Fuldendelsen som tilværelsens to modpoler. Moltmanns intention med den doksologiske trinitetslære er god nok, men ikke overbevisende, fordi han stik imod hensigten ender i en slags spekulativ udfoldelse af det trinitariske Nærvær.

Den fælles oprindelige og yderst prisværdige intention om at forsvare kristendommens aktualitet og ontologiske relevans ved at nedtone sondringen mellem den økonomiske og immanente trinitetslære lykkes altså for mig at se bedst i Grundtvigs teologi. Et citat af G. W. Lathrop beskriver meget godt den sammenhæng mellem sakramente, eukaristi og trinitetslære, som vi har mødt i Grundtvigs tekster. Lathrop skriver: »To give thanks at table - to eat and drink the signs of Christ, enlivened by the Spirit, in thanksgiving to God - is to be in Trinity « ${ }^{120}$.

Ikke desto mindre har Moltmanns teologi hjulpet os til at se Grundtvigs tekster i en ny sammenhæng. Begge teologer har på grund af deres fælles tanke om det trinitariske Nærvær meget at bidrage med i spørgsmålet om kristendommens fortsatte aktualitet og økumeniske fremtid. 
Både Grundtvig og Moltmann præsterer et væsentligt afsæt over Lessings »modbydeligt brede grav«. Alternativets styrke ligger, som vi har set, i den tilstræbte sammenbinding af de tre trosartikler dvs. af Skabelsen, Åbenbaringen og Nærværelsen udtrykt i tanken om det perichoresiske fællesskab som personbegrebets inderste kerne. Set nedefra gav det alternative personbegreb og nedtoningen af sondringen mellem den immanente og økonomiske trinitetslære sig udtryk i talen om henholdsvis et eukaristisk menighedsfællesskab (Grundtvig) og et messiansk og doksologisk frelseshistorisk fællesskab (Moltmann). Med andre ord implicerede tanken om »die offene Trinität « i begge forfatterskaber et nyt gudbilledlighedsbegreb.

Flere vestkirkelige teologer burde måske som Grundtvig og Moltmann løsne lidt op for angsten for at tale om en guddommelig Nærværs-erfaring og finde ny inspiration i en samtale med Østkirken og dele af den engelske kirketradition. Dette virker som et naturligt og måske nødvendigt træk i lyset af samfundets stigende europæisering og voksende globale bevidsthed.

\section{Noter}

1. Med talen om en immanent og økumenisk trinitetslære hentydes der til en teologisk skelnen mellem Gud som et transcendent subjekt (Gott an sich) og Gud, som han åbenbarer sig for verden (Gott für mich).

2. Se Laurence W. Woods artikel i The Asbury Theological Journal, 1993, vol 48, s. 50, hvor han bruger ordet "Christomonism«.

3. Grundtvigs Sang-Vaerk (GSV), Det Danske Forlag, København 1944.

4. Grundtvigs prædikener fra $1837 \mathrm{er}$ samlet af Chr. Thodberg, G. E. C. Gads Forlag, København 1985, bind 10.

5. Chr. Thodberg taler om »Grundtvigs græske vækkelse« (Grundtvig og grundtvigianismen i nyt lys, Forlaget ANIS, København 1983, s. 180ff.).

6. Kirche in der Kraft des Geistes (KKG), Chr. Kaiser Verlag, München 1975.

7. Erfarhrungen Theologischen Denkens (ETD), Chr. Kaiser Verlag, Gütersloh 1999.

8. Se f.eks. A.M. Allchin (professor ved Bangor University i Wales),der gennem sin interesse for Grundtvigs salmer har hjulpet til med at internationalisere Grundtvig-forskningen. Hans Grundtvig-biografi $N . F . S$. Grundtvig, An introduction to his Life and Work (Aarhus University Press, 
Aarhus 1997) har været en vigtig inspirationskilde i forsøget på at forsvare Grundtvig-litteraturens vedvarende økumeniske relevans.

9. Se Moltmanns artikel i Theologische Literaturzeitung, no. 10, okt. 1982, s. 705ff, og i bogen Trinität, Aktuelle Perspektiven der Theologie, red. af W. Breuning, Herder, Freiburg 1984, og mere udførligt i Der Geist des Lebens, Chr. Kaiser Verlag, München 1991, s. 303ff.

10. Se Moltmann, 1991 (note 9) s. 304.

11. Se Moltmann, 1984 (note 9) s. $98 \mathrm{ff}$. Se desuden N. A. Nissiotis, Die Theologie der Ostkirche im ökumenischen Dialog, Evangelisches Verlagswerk, Stuttgart 1968, s. 28 og A. M. Allchin, 1997, (note 8) s. 200.

12. I forbindelse med trinitetslæren fremhæves ofte den oldkirkelige sentens: una substantia - tres personae, som allerede kendes fra Tertullians og Augustins tekster. Denne sentens refererer til trinitetslærens evige dilemma, der består i vanskeligheden ved at ville balancere mellem en for stor vægtlægning enten på Guds enhed (monoteisme) eller på de tre personers individuelle særpræg (triteisme, polyteisme).

13. Modalisme betyder, at de tre personer reduceres til værensmåder eller fremtrædelsesformer af den ene guddommelige substans. Se f.eks. Moltmann 1982 (note 9) s. 707.

14. Op igennem kirkehistorien er termen nexus amoris blevet vedhæftet den 3. trosartikel i et forsøg på at identificere Helligånden med den relationelle forbindelse mellem Faderen og Sønnen.

15. Se H. Thomsens meget klargørende artikel om Moltmanns teologiske fronter i bogen Verbum Dei - Verbum ecclesiae, red. af T. Jørgensen og P. Widmann, Aarhus Universitetsforlag, Aarhus 1996, s. 74-100. Artiklen hedder Moltmanns teologiske historieopfattelse som et trinitarisk formuleret svar på lidelsens problem.

16. Se f.eks. Moltmann, 1984 (note 9) s. 99f. og Trinität und Reich Gottes, Chr. Kaiser Verlag, München 1980, s. 154ff.

17. Når Barth, foruden især Karl Rahner, gang på gang bringes på banen som talsmand for den monarkiske tradition, er det spørgsmålet, om Moltmann yder Barth fuld retfærdighed(se hertil H. Thomsen, 1996 (note 15) s. 100). Moltmann er sig sin barthianske arv bevidst (se Moltmann, ETD, (note 7) s. 15), men når det kommer til en kritik af det barthianske, er der en tendens til, at Moltmann ikke tager Barths egen nedtoning af sit tidlige ensidige »senkrecht von oben« udgangspunkt alvorligt. Læser man alene Barth i Moltmanns gengivelse, skulle man tro, at han aldrig skrev andet end Romerbrevskommentaren. Takket være Barth fik kristologien trods alt på ny en trinitarisk drejning, som også Moltmann skylder ham tak for.

18. Se A. M. Allchin, der i sin artikel i Grundtvig Studier fra 1990 Grundtvig Seen in Ecumenical Perspective skriver, at »the nearness of God « er et af de væsentligste motiver i Grundtvigs tankeverden (s. 105), og metodisten 
L. W. Wood, der i sin artikel om Moltmann i The Asbury Theological Journal,1993 (note 2) fremhæver Moltmanns »emphasis on the nearness of God« (s. 65).

I de to teologers forsvar for et trinitarisk guddommeligt Nærvær lurer imidlertid en fare for, at Nærværet understreges så kraftigt, at Gud helt opsluges af historien. Denne fare er især Grundtvigs teologi fra kritiske røster blevet konfronteret med. Faren må dog siges at blive afværget gennem Grundtvigs tale om "Skaber-Ordet « over for 》Gienlydsordet " (se s. 92ff). Hos Moltmann er det eskatologiske fokus, selv i hans senere forfatterskab, generelt endnu mere eksplicit.

19. Se Moltmann, 1991 (note 9) s. 312.

20. Dog bør det nævnes, at væsentlige økumeniske tiltag, som det især er kommet til udtryk i nadverdialogerne i de seneste år, endelig har erkendt det mulige frugtbare udbytte af en genoptaget dialog med Østkirkens trinitariske og eukaristiske teologi (se s. 100).

21. L. W. Wood, 1993 (note 2) s. 68.

22. Se Moltmann, Der Weg Jesu Christi, Chr. Kaiser Verlag, Munchen 1989, s. $7 \mathrm{f}$ og M. Dröge, Kirche in der Vielfalt des Geistes, Neukirchener Verlag, Neukirchen 2000, s. 12ff.

23. Se H. Thomsen, 1996 (note 15) s. $83 \mathrm{ff}$. og M. Dröge, 2000 (note 22) s. $34 \mathrm{ff}$.

24. Se Moltmann, 1991 (note 9) s. 307 og N. A. Nissiotis, 1968 (note 11) s. 26.

25. Begrebet Perichoresis blev oprindeligt introduceret af den græske kirkefader: Johannes af Damaskus.

26. ETD (note 7) s. 274ff.

27. Moltmann, ETD (note 7) s. 277. Se endvidere R. Bauckham, der i sin analyse af Moltmanns teologi beskriver det perichoresiske virkelighedssyn på følgende måde: »For Moltmann the key concept is reciprocal indwelling, most simply and commonly expressed as: »God in the world, and the world in God « (R. Bauckham, The Theology of J. Moltmann, T \& T Clark, Edinburgh 1995, s. 243).

28. Se A. M. Allchin, der taler om »the dance of love« (A. M. Allchin, 1997 (note 8) s. 136).

29. A. M. Allchin, 1997 (note 8) s. 136.

30. Se Chalcedonese (451) Teologiske tekster, Aarhus Universitetsforlag, Aarhus 1994, s. 23.

31. Se Moltmann, ETD (note 7) s. 271 og s. 277 og A. M. Allchin, 1997 (note 8) s. 136.

32. Se f.eks. Grundtvigs prædiken til 2. Søndag efter Påske, 1837 (note 4) s. 188 og GSV 5 (note 3) Guds-Ordet til os (1863) no. 232, strofe 7. Moltmann går i sin bog, Der gekreuzigte Gott endog så langt som til at beskrive Gud som den lidende elsker, der berøres dybt af verdens sorg. 
Kristi kors fortæller ifølge Moltmann ikke i første omgang om menneskets synd men langt mere om Guds medlevende kærlighed, der involverer Gud i verdenshistoriens forløb (Der gekreuzigte Gott, Chr. Kaiser Verlag, München 1981).

33. Moltmann, 1981 (note 32).

34. Se f.eks. Moltmann, 1984 (note 9) s. 111.

35. Som illustrativt eksempel kan fremhæves det oprindeligt keltiske symbol Triskelen eller Triquetaen, der viser triniteten indtegnet $i$ en kosmisk cirkel (se f.eks. L. Gotfredsen, H. J. Frederiksen, Troens Billeder-Romansk kunst i Danmark, Systime, Herning 1993, s. 59).

36. Se H. Thomsen, 1996 (note 15) s. $75 \mathrm{ff}$.

37. Se Chr. Thodbergs artikel i Grundtvig Studier 2000, s. 118ff.

38. Se H. Thomsen, 1996 (note 15) s. 78.

39. Se f.eks. imponerende værker som Dantes La Divina Commedia og Miltons Paradise Lost, der viser en helt anden form for kristen poesi, end den Grundtvig leverede.

40. Diskussionen har især drejet sig om forskellen mellem et substans-ontologisk nadversyn og et nadversyn, der betoner Kristi legemlige Nærværelse i nadverens elementer og en symbolsk nadverlære, der betoner Nærværets spirituelle karakter. Det første nadversyn møder man i den katolske transsubstantiationslære og den lutherske ortodoksis nadverteologi; det andet nadversyn derimod møder man i den reformerte tradition.

41. Se E. Kyndal, der i sin gennemgang af Luthers nadversyn i bogen, Nadverloere og Nadverfollesskab (G. E. C. Gads Forlag, København 1984) gør sig til talsmand for at forlade den gængse tolkning af Luthers nadversyn som en substansontologisk realpræsenslære muliggjort af ubiquitetslæren om Kristi legemlige allestedsnærværelse. Kyndal fokuserer i stedet for på Ordets altafgørende betydning for Luthers tanker om realpræsens. Har Kyndal ret, griber Grundtvig altså bagom den lutherske ortodoksi for at videregive tankemønstre fra Luther selv.

42. Se J. H. Schjørring, Grundtvig og Påsken, G. E. C. Gads Forlag, København 1987, s. 132 og H. Høirup, Fra Døden til Livet, G. E. C. Gads Forlag, København 1983, s. 89ff.

43. I Den Christelige Børnelordom skriver Grundtvig selv, at han følte »en dyb Trang til et kjendeligt Ord af Herrens egen Mund, der kunde tjene til en gyldig Regel baade for Menighedens Fælles-Tro og den kristelige Lærdom og Skrift-Fortolkning, og som tillige kunde være et guddommeligt Meddelelses-Middel for Aanden og Livet« og han fortsætter: »den Trang var det, jeg fandt, og er det, jeg daglig klarere og gladere finder tilfredsstillet ved Sakrament-Ordet «(Den Christelige Børneloerdom, udg. 1868; Udvalgte Skrifter, ved Holger Begtrup, Gyldendals Forlag, København 1906, bind 4, s. 348). Se desuden prædikenen til Søndag efter 
Påske 1837 (note 4) den indledende bøn, s. 185 og GSV 2 (note 3) Christus-Riget (1850) no. 134, strofe 2.

Foruden ved døbefonten og nadverbordet mener Grundtvig at høre og genkende Guds fortsatte tiltale i Kristi imperativiske udbrud i evangelierne, under velsignelsen, fredslysningen og i form af Fadervor.

44. Se GSV 5 (note 3) I Begyndelsen var Ordet (1860-62) no. 193, strofe 7.

45. Se G. Wainwright, Doxology, Epworth Press, London 1980, s. 3 og s. 10.

46. Se prædikenen til Christi Himmelfartsdag 1837 (note 4) s. 213. Se desuden J. H. Schjørring, 1987 (note 42) s. 33.

47. I modsætning til Hegel, der bygger sit historiesyn op som en dipolær syntesetænkning, fokuserer Grundtvig især på det kontinuerlige i historien.

48. Se f.eks. salmen: Denne er dagen, som Herren har gjort! ... GSV 1 (note 3) no. 134 (1837)).

49. Se J. H. Schjørring, Grundtvigs Billedsprog, Forlaget ANIS, København 1990, s. 100ff.

50. Se Chr. Thodberg, 2000 (note 37).

51. Se f.eks. GSV 4 (note 3) Hvor skal jeg Gud Billed finde? (1850-51) no. 212 og GSV 5, I Begyndelsen var Ordet (1860-62) no. 193, strofe 1-2 og 7 , hvor Grundtvig skriver, at »Gienlyds-Ordet Havde ingen Skaber-Evne» i modsætning til Guds Ord, som "Skabde alt med Guddoms-Evne«.

52. Se f.eks. GSV 5 (note 3) Guds-Ordet til os (1863) no. 232.

53. Se Den Christelige Børneloerdom (note 43) s. 345, hvor Grundtvig taler om "Nadveren, som Bordet i Guds Rige«.

54. Se Den Christelige Børnelordom (note 43) s. 344.

55. Se GSV 4 (note 3) Midt iblandt os er Guds Rige (1853) no. 266, strofe 4. Grundtvig trækker her på nadvertraditionen fra Markus og Matthæus, hvor Kristus taler om »den nye frugt i Guds rige«. Sammenlign GSV 1 (note 3) For-Spil, (1824) strofe 31 med Mk. 14.25/ Mtt. 26.29.

56. E. Kyndal, 1984 (note 41) s. 20. Se desuden Paulus' tale om kirken som Kristi legeme og menigheden som Kristi lemmer. Sammenlign Grundtvigs prædiken til Skærtorsdag 1837 (note 4) s. 65 med 1.Kor. 10.17 og 12.27.

57. GSV 1 (note 3) Søndag er vor Herres Dag (1837) no. 136, strofe 7.

58. Den Christelige Børneloerdom, (note 43) s. 347.

59. Se forrige afsnit note 54 .

60. Se R. Prenters artikel i: Grundtvig, Theolog og Kirkelcerer, udg. af Udvalget for Konvent for kirke og teologi, Sabro, 1983, s. 69ff. samt P. Borums og M. Mortensens tavler over Grundtvigs trinitariske system, note 13 i samme artikel.

61. Denne tanke driver unægteligt på Joh. 3.16ff. og minder om Moltmanns udfoldelse af korset som et bevis på Guds kærlighed i bogen, Der Gekreuzigte Gott (note 32). 
62. Skærtorsdagsprædiken 1837 (note 4), s. 162. Se endvidere GSV 1 (note 3) For-Spil, (1824) strofe 9, hvor Grundtvig med reference til Kristi korsdød omtaler nadveren som »Kærlighedens Kalk «.

63. Se For Sammenhoengens skyld, red. af Chr. Thodberg, Aarhus Universitetsforlag, Aarhus 1977, s. 188.

64. Se note 51.

65. Den Danske Salmebog (DDS), København 1986, Velsignelse, al jordens $\operatorname{tarv}(1862)$ no. 387.

66. A. Schmemann, The World as Sacrament, Darton, Longman \& Todd, London 1965, s. 28.

67. K. Barth, Die Kirchliche Dogmatik IV, 2 § 64 (1955), (genudgivet af Theologischer Verlag, Zürich 1993) s. 39 og s. 137. Hos Barth udtrykkes den kiastiske asymmetri i tanken om, at Teologiens "Seingrund (den åbenbarede Gud eller Åbenbaringen) er identisk med teologiens »Erkenntnisgrund « (den erkendte Gud eller åbenbaringen om Åbenbaringen).

68. G. Wainwright, 1980 (note 45) s. 21.

69. G. Wainwright, 1980 (note 45) s. 1 og s. $8 \mathrm{ff}$.

70. Se J. Balling, Kristendommen, Politikens Forlag, København 1996, s. 44.

71. Se Grundtvigs økumeniske prædiken til 2. Påskedag 1837 (note 4) s. $185 \mathrm{ff}$.

72. Nok mente Grundtvig, at dåben er indgangen til et liv i »kriste-lighed « og taler i salme 134 i GSV 1 (note 3) (Denne er Dagen, som Herren har gjort! (1837) strofe 4) om »de indviede Tunger«, men tager man det skabelsestrinitariske fundament for Grundtvigs liturgi alvorligt og ihukommer Christenhedens Syvstjerne (1860, udg. af Th. Balslev, Kirkeligt Samfunds Forlag, København 1955), som henlægger den syvende menighed til Indien (s. 244ff, strofe 78-91), må Grundtvigs teologi snarere siges at indeholde en form for inklusivistisk tendens. Det, der konstituerer kirken, er ikke menigheden eller Kristus-alene men den treenige Gud, der i sit universelle virke fra Urzeit til Endzeit integrerer hele verden i sin historie.

73. Grundtvig hævder til tider, at det doksologiske menighedsfællesskab blander sig med englenes himmelkor: »Lovsangen fra den frelste Jord, Sig blander med dit Engle-Chor" (GSV 1 (note 3) O store Gud! Vi love Dig (1837) no. 14, strofe 3). Et andet sted taler han om, at Guds engle vandrer op og ned »Paa Psalmens Tone-Stige« (GSV 1 (note 3) Velkommen igien Guds engle smaa (1837) no. 197, strofe 7).

74. Se f.eks. GSV 1 (note 3) Kirken det er et gammelt Huus (1837) no. 22, strofe 7 og GSV 5, I Begyndelsen var Ordet (1860-62) no. 193, strofe 6 og 8.

75. Se $D D S$ (note 65) I al sin glans nu stråler solen (1843) no. 247, strofe 5.

76. E. Kyndal, 1984 (note 41) s. 80ff. Jf. det græske ord for nadver: eukaristi,

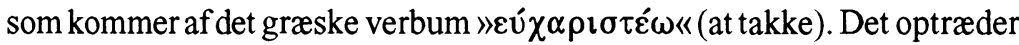
i nadverteksten hos Paulus og Lukas. Forstavelsen »eu«- indvarsler altid 
et positivt aspekt. Dermed understreges igen Grundtvigs fremhævelse af glædesaspektet i forbindelse med nadveren.

77. DDS (note 65) Lov og tak og evig are (1863) no. 54, strofe 1.

78. Se Schmemann, 1965 (note 66).

79. GSV 1 (note 3) Jeg veed et lille Himmerig (1837) no. 137, strofe 20.

80. Schmemann, 1965 (note 66) s. $40 \mathrm{ff}$.

81. DDS (note 65) I al sin glans nu stråler solen (1843) no. 247, strofe 6.

82. G. Wainwright, 1980 (note 45) s. 271.

83. Wainwright, 1980 (note 45) s. 273. Se endvidere Luthers henvisning til en nødvendig distinktion mellem Kristi offer og vores takkeoffer (Fragmenter af et Spejl, red. af N. H. Gregersen, Forlaget ANIS, København 1993, s. 242).

84. GSV 1 (note 3) O Hellig-Aand! Som Pindse-Dag (1837) no. 379, strofe 3.

85. »Faith and Order, oprindeligt stiftet i Lausanne i 1927; fra 1948 en kommission under Kirkernes Verdensråd for drøftelse af lære- og kirkeordnings spørgsmål« (Teologiske Tekster (note 30), s. 447).

86. Se Teologiske Tekster (note 30) s. 469ff.

87. Se ETD (note 7) s. 44f. På s. 45 bruger Moltmann ordet: „Simultanpräsenz«.

88. Moltmann skriver selv, at han vil »en treleddet dialektik« og taler som Augustin om, at »Tempora sunt tria« (Moltmann, Gott in der Schöpfung, Chr. Kaiser Verlag, München 1985, s. 21 ff. og $K K G$ (note 6) s. 269, note 73).

89. Se ETD (note 7) s. 45.

90. Især Moltmanns tidlige værker vidner om inspirationen fra Ernst Blochs historiske filosofi, der ligeledes har til hensigt at sammentænke tidsmodeller og eksistensvilkår. I den filosofiske udgave af den tripolære tidsopfattelse tales der om nutiden spændt ud mellem »Wirchlichkeit« og »Möglichkeit« (se Moltmanns artikel i God Will be All in All, red. af R. Bauckham, T \& T Clark, Edinburgh 1999, s. 227ff. og ETD (note 7) s. 40).

91. Moltmann taler om nadveren som »das Sakrament der Zeit» og »das wahre Geschichtszeichen« (ETD (note 7) s. 44f.).

92. $K K G$ (note 6) s. 228.

93. Se $E T D$ (note 7) s. 274, hvor Moltmann selv er inde på forskellene mellem sine tidlige og senere tanker.

94. ETD (note 7) s. 286.

95. ETD (note 7) s. $289 \mathrm{f}$.

96. M. Dröge, 2000 (note 22) s. $229 \mathrm{ff}$.

97. ETD (note 7) s. 290.

98. Moltmann, 1985 (note 88) s. 264. 
99. Se f.eks. Moltmann, 1985 (note 88) s. 238 og citatet: »Die Trinität ist unser Sozialprogramm " (note 95). Trinitetslærens sociale og samfundsmæssige relevans er i de senere år kommet til at udgøre en ny spændende niche af trinitetslære. Foruden Moltmann har bl.a. den græsk-ortodokse teolog, N. Federov og M. Volf beskæftiget sig med triniteten som et socialt program.

100. Moltmann 1982 (note 9) s. 710.

101. $K K G$ (note 6) s. 222.

102. E. Kyndal, 1984 (note 41) s. 216, hvor Kyndal fremhæver Moltmann som et nutidigt bevis på den græsk-ortodokse påvirkning, der som sagt $i$ de seneste år har præget nadverdiskussionen.

103. $K K G$ (note 6) s. 276.

104. $K K G$ (note 6) s. 277.

105. Moltmann, 1984 (note 9) s. 113.

106. Se H. Thomsens artikel, 1996 (note 15) s. 96, hvor han citerer Moltmann: »Die im Kreuzestod Jesu auf Golgatha konkrete »Geschichte Gottes» hat darum alle Tiefen und Abgründe der menschlichen Geschichte in sich und kann darum als die Geschichte der Geschichte verstanden werden« (Moltmann, 1981 (note 32) s. 233).

107. Se Moltmanns artikel i bogen God Will be All in All (note 90) s. 227, hvor han imødekommer denne kritik fra eksegeten R. Bauckham. Den efterfølgende gengivelse af Moltmanns metode er inspireret af denne artikel.

108. Se M. Dröge, 2000 (note 22) s. $12 \mathrm{ff}$.

109. Se $E T D$ (note 7) s. 36 og s. 291.

110. Se f.eks. GSV 1 (note 3) Jeg veed et lille Himmerig (1837) no. 137, strofe 3 og 9 og Jeg som et Barn mig glode vil (1837) no.196, strofe 1 og 3.

111. Moltmann, 1984 (note 9) s. 105.

112. Moltmann, 1982 (note 9) s. 714.

113. R. Bauckham, 1995 (note 27) s. 166ff.

114. Se f.eks. Moltmann, Trinität und Reich Gottes, Chr. Kaiser Verlag, München 1980, s. 178.

115. Se H. Thomsen, 1996 (note 15) s. 91.

116. H. Thomsen, 1996 (note 15) s. 99.

117. H. Thomsens udtryk, 1996 (note 15) s. 99.

118. Helbredelses-, eksorcisme- og opstandelsesunderne i evangelierne beviser ifølge Grundtvig,at Kristi befaling er analog med virkelighedens beskaffenhed - akkurat, som det var tilfældet i Skabelsen, da Gud skabte verden gennem sit ord.

119. For Sammenhoengens Skyld (note 63) s. 64. 
120. G. W. Lathrop: Holy Things, A liturgical Theology, Fortress Press, Minneapolis 1993, s. 138. 